\title{
INCAGUASI, "DONDE DORMÍAN LAS CARRETAS". ARQUEOLOGÍA DE UN LUGAR DE PASO EN EL VALLE DEL ALTO LOA, DESIERTO DE ATACAMA
}

\author{
INCAGUASI, "WHERE THE CARTS SLEPT". ARCHAEOLOGY OF A \\ PASSING PLACE IN THE ALTO LOA VALLEY, DESERT OF ATACAMA
}

José Berenguer R. ${ }^{1}$ y Diego Salazar S. ${ }^{2}$

\begin{abstract}
Resumen
Este artículo busca contribuir al estudio de la circulación humana en los espacios internodales, investigando lugares de uso pasajero en zonas áridas o semi áridas. La investigación se concentra en una específica localidad: Incaguasi (región de Antofagasta, Chile), un desértico paraje actualmente deshabitado del valle superior del río Loa que ha funcionado como sitio de travesía para los viajeros desde a lo menos 1200 DC. La arqueología y las fuentes históricas nos han permitido desvelar la historia ocupacional de Incaguasi como lugar de paso, las actividades realizadas allí a lo largo de ocho siglos y los cambios y continuidades a través de los períodos Intermedio Tardío, Inka, Colonial, Boliviano y Chileno.
\end{abstract}

Palabras claves: Norte de Chile - espacios internodales - circulación lugares de paso - historia ocupacional.

\begin{abstract}
This paper aims to make a contribution to the study of the human circulation in internodal spaces by studying passing places in arid and semi-arid zones. Research focuses in a specific locality: Incaguasi (Antofagasta Region, Chile), a currently uninhabited landscape in the upper ravine of the Loa river, a crossing point to travellers from at least $\mathrm{AD} 1200$. Archaeological and historical records have permitted us to unveil the occupational history of Incaguasi as a transito staging post, the activities carried on this place over eight centuries, and changes and continuities over the Late Intermediate, Late or Inka, Colonial, Bolivian and Chilean periods.
\end{abstract}

Abstract

Keywords: Northern Chile - internodal spaces - circulation - passing places - occupational history.

Recibido: marzo 2016. Aceptado: diciembre 2016

\section{* InTRoducción}

El Incaguasi referido en este artículo se encuentra en el interior de la región de Antofagasta (Chile), a $50 \mathrm{~km}$ al noreste de Calama ( $538515 \mathrm{E} / 7556755 \mathrm{~N})$, sobre la planicie occidental del valle superior del río Loa, en un hiperárido paraje completamente deshabitado. La memoria local recuerda este lugar como un sitio de descanso, un corral o una parada de carretas (Gisoc 2009); los documentos históricos lo mencionan como una posta boliviana (p.e., Bertrand 1885; Cajías 1975); los diccionarios geográficos lo presentan como un caserío habitado (Astaburuaga Cienfuegos 1899) o una posta abandonada (Risopatrón 1924); la Carta "Conchi", Escala 1:50.000, lo asocia al topónimo "Establo" (IGM 2003); y la arqueología lo define como un asentamiento incaico (Cornejo 1995) o un tambo incaico (Aldunate 2001a; Stehberg 2001). Mostraremos en las páginas siguientes que todas estas denominaciones $y / o$ caracterizaciones podrían ser correctas, $y$ que, además, existen evidencias arqueológicas para definirlo como una antigua paskana o paradero de caravanas de llamas.

La investigación sistemática de este lugar comenzó en 2001, con el proyecto "Arqueología del sistema vial de los inkas en el Alto Loa, segunda región", cuyo objetivo fue obtener una visión más profunda de los vínculos del Tawantinsuyu en la región de Antofagasta investigando caminos, instalaciones y otros rasgos laterales al Qhapaq Ñan

1 Museo Chileno de Arte Precolombino, Bandera 361, Santiago, CHILE. Email: jberenguer@museoprecolombino.cl,

2 Departamento de Antropología, Universidad de Chile, Ignacio Carrera Pinto, 1045, Piso 2, Nuñoa, Santiago, CHILE. Email: dsalazar@ uchile.cl 


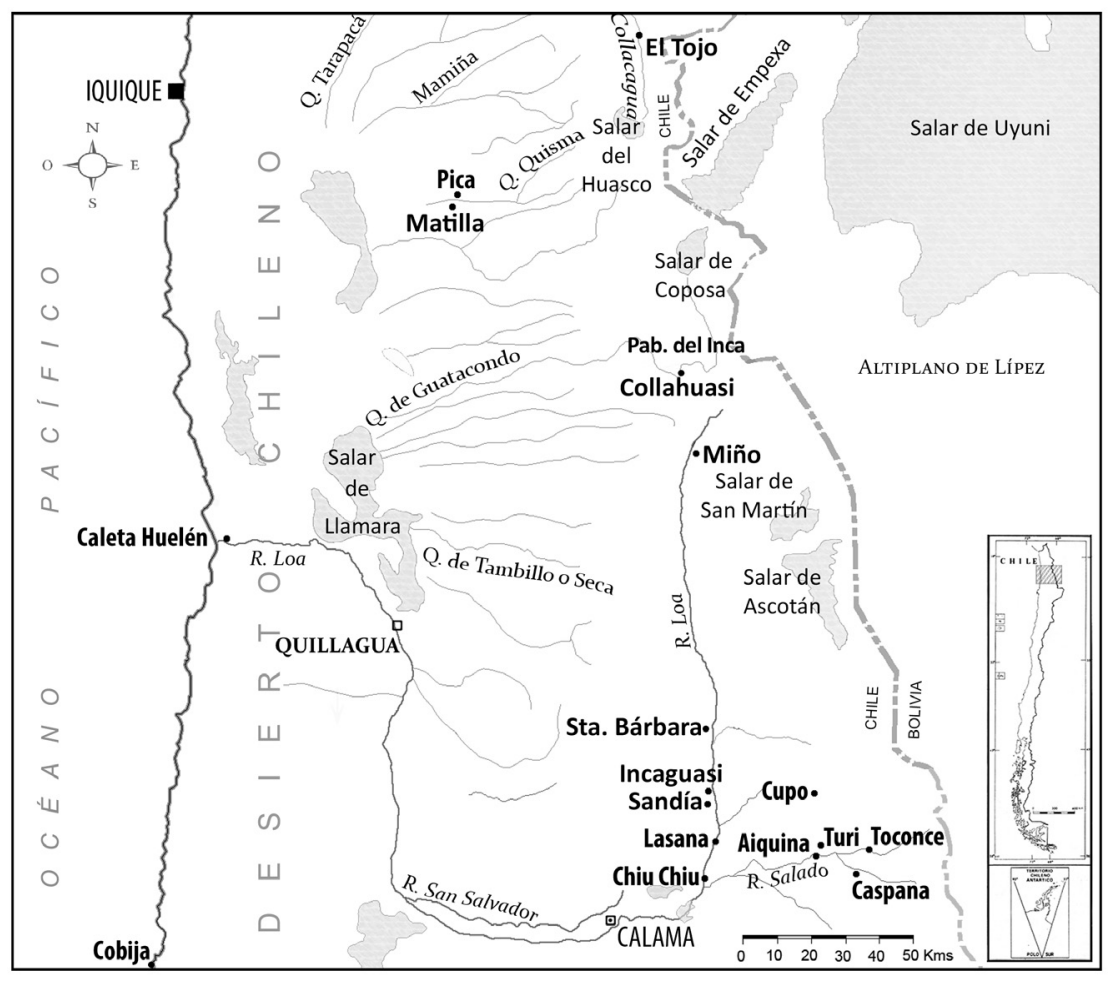

Figura 1. Mapa de las regiones de Tarapacá y Antofagasta con los principales topónimos mencionados en el texto.

en esta zona del río Loa. ${ }^{1}$ Aquella parte del proyecto relacionada con Incaguasi comprendió prospecciones, recolecciones y excavaciones arqueológicas. El interés investigativo por Incaguasi se reanudó en 2010, en el marco del "Proyecto Arqueológico El Abra", con nuevas excavaciones cuya finalidad fue vincular la ocupación incaica del sitio con el Complejo Minero San José del Abra, ubicado unos $30 \mathrm{~km}$ al noroeste. ${ }^{2}$ Pese al tiempo transcurrido, hasta ahora solo se han dado a conocer resultados parciales, los que, por añadidura, se hallan dispersos en diferentes trabajos (González 2005; Sanhueza 2005, 2012; Uribe y Cabello 2005; Méndez 2007), en artículos de síntesis con descripciones demasiado escuetas (Berenguer 2007; Berenguer et al. 2005; Salazar et al. 2013) y en informes técnicos que permanecen inéditos. Estos resultados son discutidos en este artículo en forma unitaria.

Presentamos este trabajo dentro del marco del "Simposio Estudios de Espacios Internodales” (XX Congreso Nacio-

1 Proyecto Fondecyt $\mathrm{N}^{\circ}$ 1010327, "Arqueología del sistema vial de los incas en el Alto Loa, segunda región”, dirigido por José Berenguer.

2 "Proyecto Arqueológico El Abra", conducido por Diego Salazar con financiamiento de SCM El Abra. nal de Arqueología Chilena), toda vez que parajes como Incaguasi caen dentro de la categoría de lugares de paso, tan propios de la circulación por los internodos, entendiendo por "circulación" el movimiento de personas, animales, objetos e información a través del espacio geográfico. Los lugares de paso suelen incluir sitios de travesía, colocados lateralmente a los recorridos, creados por el movimiento de generaciones de caminantes, usados en forma más transitoria y esporádica que permanente o continua, y, a veces, solo posibles de ver cuando estos espacios son recorridos a pie (Barnard y Wendrich 2008; Careri 2009; Snead et al. 2009; Ingold 2011). Explorando la historia ocupacional de Incaguasi como un lugar de uso pasajero, la naturaleza de las actividades realizadas allí y los cambios y continuidades producidos en la utilización del lugar a lo largo del tiempo, nuestra investigación busca aportar al conocimiento de la circulación por los espacios internodales en zonas áridas o semiáridas (Berenguer 1994a, 1995, 2004a, 2010; Berenguer y Pimentel 2010; Nielsen 1997, 2006, 2013; Pimentel 2005, 2009; Pimentel et al. 2011). En particular, nuestro objetivo es el proceso histórico visto desde un pequeño punto del desierto que fue reiteradamente usado para articular las redes de tráfico regional. 


\section{* Marco geográfico y antecedentes sobre CIRCULACIÓN}

Antes de entrar en materia es preciso referirse en forma sucinta a la geografía del Alto Loa y a la información disponible sobre la circulación humana en este valle (Figura 1).

\section{El valle del Alto Loa}

El curso superior del río Loa -más conocido como Alto Loa- se extiende desde las nacientes de este río, en Miño, a unos $4000 \mathrm{msnm}$ (región de Tarapacá), hasta su confluencia con el río Salado, aproximadamente a 2500 msnm (región de Antofagasta). ${ }^{3}$ Es éste un valle de origen tectónico de casi $150 \mathrm{~km}$ de largo, 20 a $25 \mathrm{~km}$ de ancho y orientación meridiana, que desciende al sur flanqueado por dos cadenas montañosas: al oriente, la Cordillera Andina, un cordón volcánico relativamente nuevo, y al poniente, la Sierra del Medio, donde se encuentran las mayores reservas de cobre del mundo y cuyos yacimientos han sido explotados desde tiempos prehispánicos. De ambas cadenas bajan a la fosa del Loa sendos planos inclinados por los cuales ha discurrido y discurre aún gran parte de la circulación humana. Llamaremos "planicies" a estos planos inclinados y "pampas" a ciertos tramos de ellas que figuran con nombres propios en la cartografía oficial del IGM.

Entre Miño y Santa Bárbara prevalece un clima de desierto marginal de altura y aguas más abajo, uno desértico normal. Por debajo de los $3100 \mathrm{msnm}$ la presencia de vegetación es prácticamente nula, como sucede en Incaguasi, localidad que se encuentra en un ambiente de desierto absoluto, donde, por lo tanto, las lluvias son en extremo infrecuentes. ${ }^{4}$

3 Hasta donde sabemos, la primera referencia a este brazo superior del río como "Alto Loa" se encuentra en Aldunate et al. (1983:22). Con el tiempo, el término se ha popularizado y adquirido nuevos significados. Últimamente, las comunidades indígenas de la región y algunos organismos oficiales han empezado a usar el concepto "Alto El Loa" para referirse no solo a este brazo o curso alto del río sino a toda su hoya hidrográfica superior, incluyendo la cuenca del río Salado. Para este último y más amplio uso, en este artículo reservamos el concepto de "Loa Superior" (véase Berenguer et al. 2005: 10).

4 Más detalles sobre la geografía y el medio ambiente del valle, en Berenguer (2004a: 211-220; Berenguer et al. 2005: 10-13).
La morfología del Alto Loa, con sus largas planicies y varios pasos cordilleranos, facilita la circulación por el valle y la comunicación con diversos ámbitos vecinos: al norte con el altiplano sur de Tarapacá y el altiplano central de Bolivia; al sur con el curso medio del río Loa y la hoya del río Salado; al poniente con el oasis de Quillaqua, la Quebrada de Guatacondo y los oasis de la pampa del Tamarugal; y al oriente con los salares de Ascotán y Carcote, y el altiplano de Lípez (Bolivia).

\section{La circulación por el valle}

Aparte de los circuitos de movilidad estacional de cazadores recolectores entre Chiu Chiu, Ojos de San Pedro y Santa Bárbara, que han sido inferidos para los períodos Arcaico Medio y Superior (Berenguer 2004b; De Souza 2004), y de los probables movimientos de pastorescaravaneros entre Chiu Chiu y Santa Bárbara detectados durante la Fase Carrazana, ca. 500-950 DC (Berenguer 2004a), la arqueología del Sector Santa Bárbara ha producido evidencias de tráfico de caravanas de llamas hacia comienzos del Período Intermedio Tardío, durante la Fase Laguna (ca. 950-1200 DC). No obstante, las evidencias más sólidas provienen de las fases Quinchamale I y II (ca. 1200 - 1450 DC), cuando el valle se convierte en una vital ruta de tráfico regional e interregional: huellas troperas, paraderos de caravanas, estancias vinculadas al tráfico, mesas rituales de viaje (muros y cajas), arte rupestre caravanero y ofrendas de cuentas de conchas del Pacífico, trocitos de turquesa y mineral de cobre están entre las mejores evidencias de este tipo de circulación. En esta época los nodos o áreas densamente pobladas más cercanos se encuentran en Lasana, Chiu Chiu y la cuenca alta del río Salado.

Más tarde, durante el Horizonte Tardío (ca. 1400-1535 DC), los incas trazan una arteria del Qhapaq Ñan entre Collahuasi por el norte y Lasana por el sur, y construyen una docena de instalaciones de diversos tamaños y complejidad (véase Berenguer 2007: 419, Fig. 1). El conjunto ha sido interpretado como una infraestructura para la circulación de comitivas estatales, la adoración de wak'as, el aprovisionamiento de enclaves mineros en la Sierra del Medio, el movimiento de chaskis, los contactos con la población del valle, el traslado de mitayos y el transporte hacia el exterior del mineral o del metal fundido (Berenguer et al. 2005; Berenguer 2007; Salazar et al. 2013). El centro 
político-administrativo incaico más próximo se encuentra en Turi, en la vecina cuenca alta del río Salado. ${ }^{5}$

Durante la Colonia (ca. 1540-1825), particularmente en sus primeros años, españoles e indígenas continúan explotando los yacimientos cupríferos de la Sierra del Medio y usando las planicies del valle como ruta de circulación y transporte. A esta época de contacto hispanoindígena deben corresponder unos petroglifos cercanos al Alero Santa Bárbara (SBa-11o) que muestran llameros con túnica andina y sombrero alón europeo junto a una recua de camélidos, donde uno de los individuos monta una llama como en una escena ecuestre (véase Berenguer 1999: 47, abajo izquierda). Más adelante, la movilidad por el valle seguramente estuvo ligada a la explotación de la mina de cobre de Conchi, la cual experimenta un importante auge a contar de mediados del siglo XVIII (Melero y Salazar 2003). En aquel entonces, los yacimientos mineros de la región representaban para los arrieros una fuente de trabajo y un mercado que abastecer, pero también un medio para adquirir metales, sobre todo de baja ley (Sanhueza 1991: 136). La mina de Conchi es citada por Juan del Pino Manrique (1787 [1885]) como explotada regularmente con mano de obra local y es descrita como una de las principales alternativas para los arrieros indígenas de Atacama la Baja, después del tráfico de pescado. La presencia de restos de maderas de las yungas, de diversos tipos de frutas, de cerámicas esmaltadas, carbón de queñoa, frutos de chañar y otros muchos bienes foráneos encontrados en las basuras del poblado minero colonial de Conchi (Salazar 2006) da cuenta de su integración con diversos mercados coloniales a través de rutas que debieron cruzar el Sector Santa Bárbara y, por lo menos algunas de ellas, la zona donde está Incaguasi. A fines del siglo XVIII, se describe un itinerario de correos entre Tarapacá y Copiapó a través del corredor del Loa (Bertrand 1885:289-290). ${ }^{6}$

Al independizarse Bolivia de España, en 1825, las autoridades bolivianas hacen pasar por este corredor sus rutas

\footnotetext{
5 Para un reciente análisis regional de la ocupación inca con énfasis en esa cuenca, véase Berenguer y Salazar (2017).

6 Una de las primeras referencias históricas conocidas sobre el valle mismo proviene del "Itinerario Real de Correos" establecido por las Reales Ordenanzas de 1778, que describe la ruta colonial de correos entre Tarapacá y Atacama con dirección al Reino de Chile (Cecilia Sanhueza, com. pers. 2002).
}

de correo y transporte entre Cobija y Potosí (Cajías 1975: 65-92), tráfico del que quedan varias ruinas de postas, la más nombrada de las cuales es Santa Bárbara (Risopatrón 1924; Berenguer 2004a; Berenguer et al. 2005) (aquí Figura 2). Hasta esos momentos se trataría de un tráfico puramente de transeúntes, caballos y mulas, pues solo a mediados de 1840 se constituye el uso de carretas para la vía desde Cobija al interior (González Pizarro 2006). Sin embargo, es recién en el decenio de 1870 cuando se construye "el camino destinado al gran tráfico [...] la carretera que desde la costa del Pacífico viene a terminar en Guanchaca" (Bertrand 1885: 266; véase también Sanhueza y Gundermann 2009: 114). La vía entre Chiu Chiu y Santa Bárbara iba por el oeste del río (Bertrand 1885: 261), cosa que se aprecia bien en el Mapa del teatro de la guerra (Raimondi 1879) (Figura 3). También se aprecia en este mapa que Incaguasi está emplazado al este de dicha vía. Entre tanto, Conchi sigue siendo referido como mineral: "[p]roduce cobre superior que surte a los ingenios de Portugalete: se han trabajado también algunas de sus vetas de oro" (Dalence 1851). El 9 de mayo de 1877, Chiu Chiu es destruido por un gran terremoto (Montessus de Ballore 1912; véase también Barros 2010), lo que influye en el traslado definitivo de este pueblo a la banda oriental del río Loa, donde se halla actualmente.

En la penúltima década del siglo XIX toda la región, incluido el valle del Alto Loa, pasan a manos de Chile como consecuencia de la Guerra del Pacífico, también conocida como Guerra del Salitre (1879-1883). Luego de la ocupación de Calama, en marzo de 1879, patrullas chilenas incursionan con frecuencia hacia el interior siguiendo la ruta de las antiguas postas del camino que comunicaba con los minerales de Huanchaca y Potosí, a fin de interceptar el tráfico de abastecimiento de los ejércitos boliviano y peruano, e intimidar a la población local (Sanhueza y Gundermann 2009: 225). De hecho, en julio de ese año, efectivos del ejército ocupante se instalan en la mencionada posta de Santa Bárbara para impedir dicho tráfico, pasando esta localidad a figurar en los reportes como un destacamento chileno al cuidado de dos soldados (Boletín de la Guerra del Pacífico 1979: 256, 452). Desde Santa Bárbara no solo se vigila la ruta de las postas a Potosí, sino también el resto del corredor del Loa, el que, valle arriba, conecta con Tarapacá vía Miño, Guatacondo, quebrada de Cana, Altos de Chacarillas, Pica y salar de Huasco (Boletín de la Guerra del Pacífico 


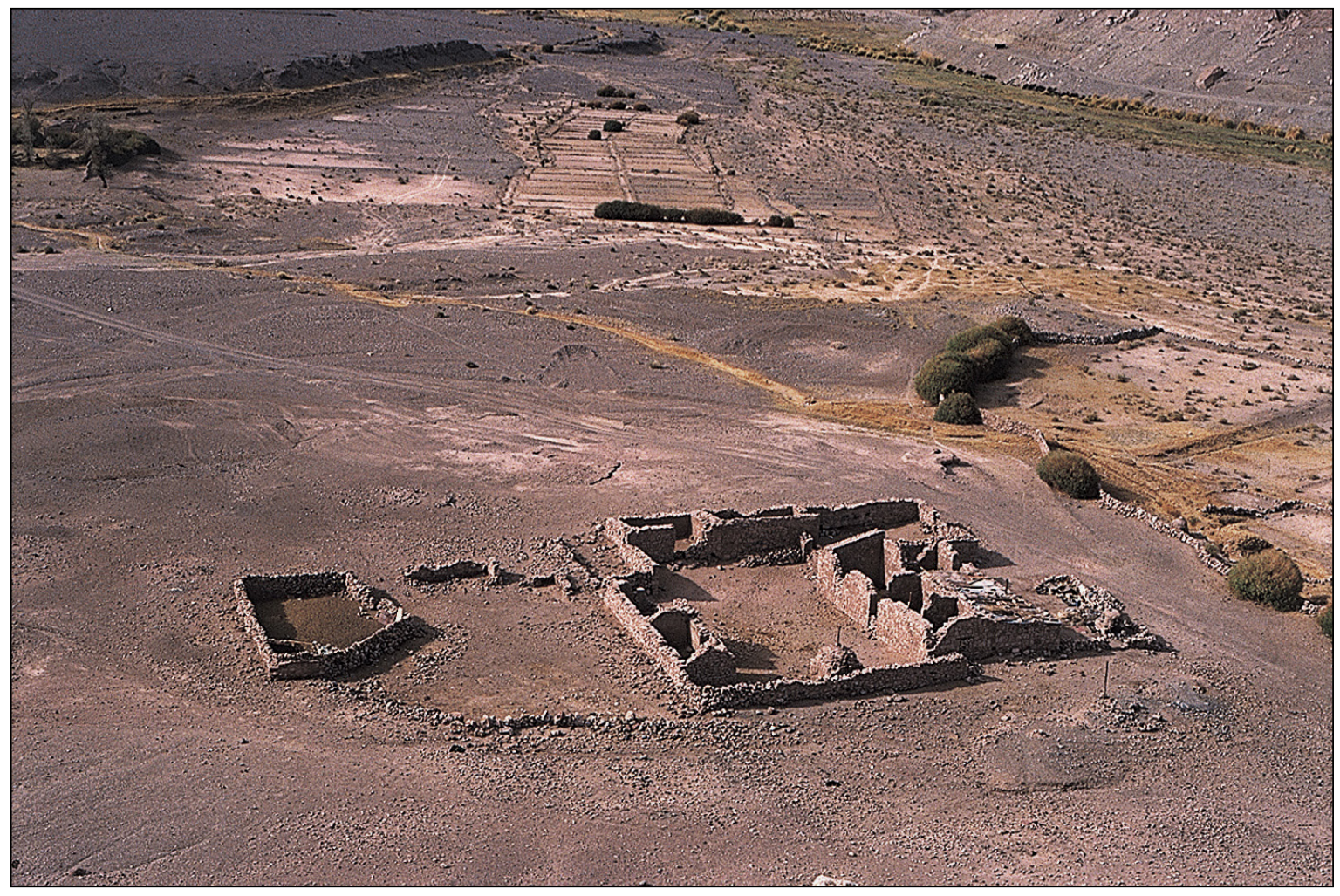

Figura 2. Ruinas de la posta de Santa Bárbara vista desde el sur, 1999 (foto J. Berenguer).

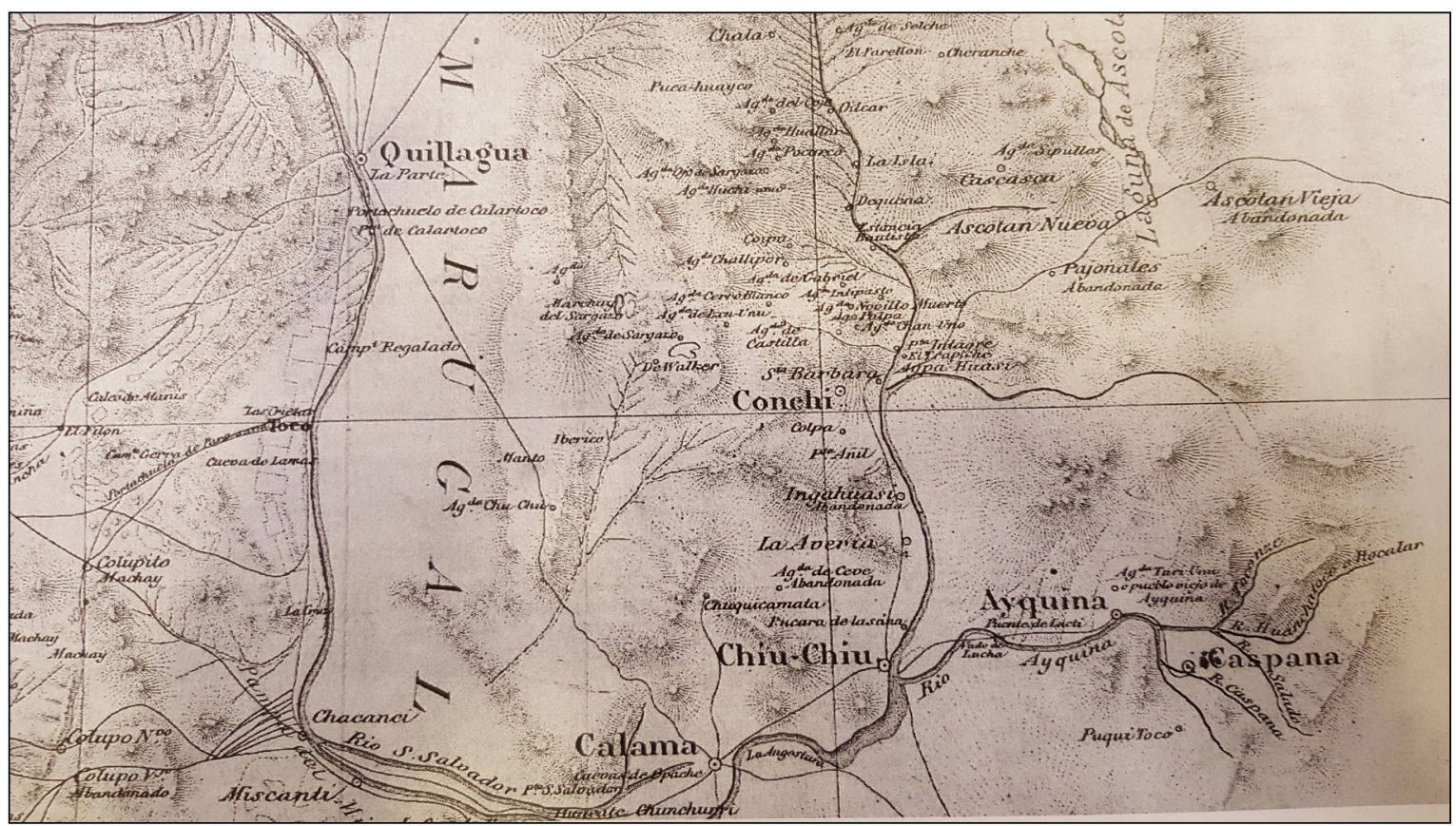

Figura 3. Extracto del Mapa del teatro de la guerra publicado por Raimondi en 1879 (cortesía Alonso Barros). 


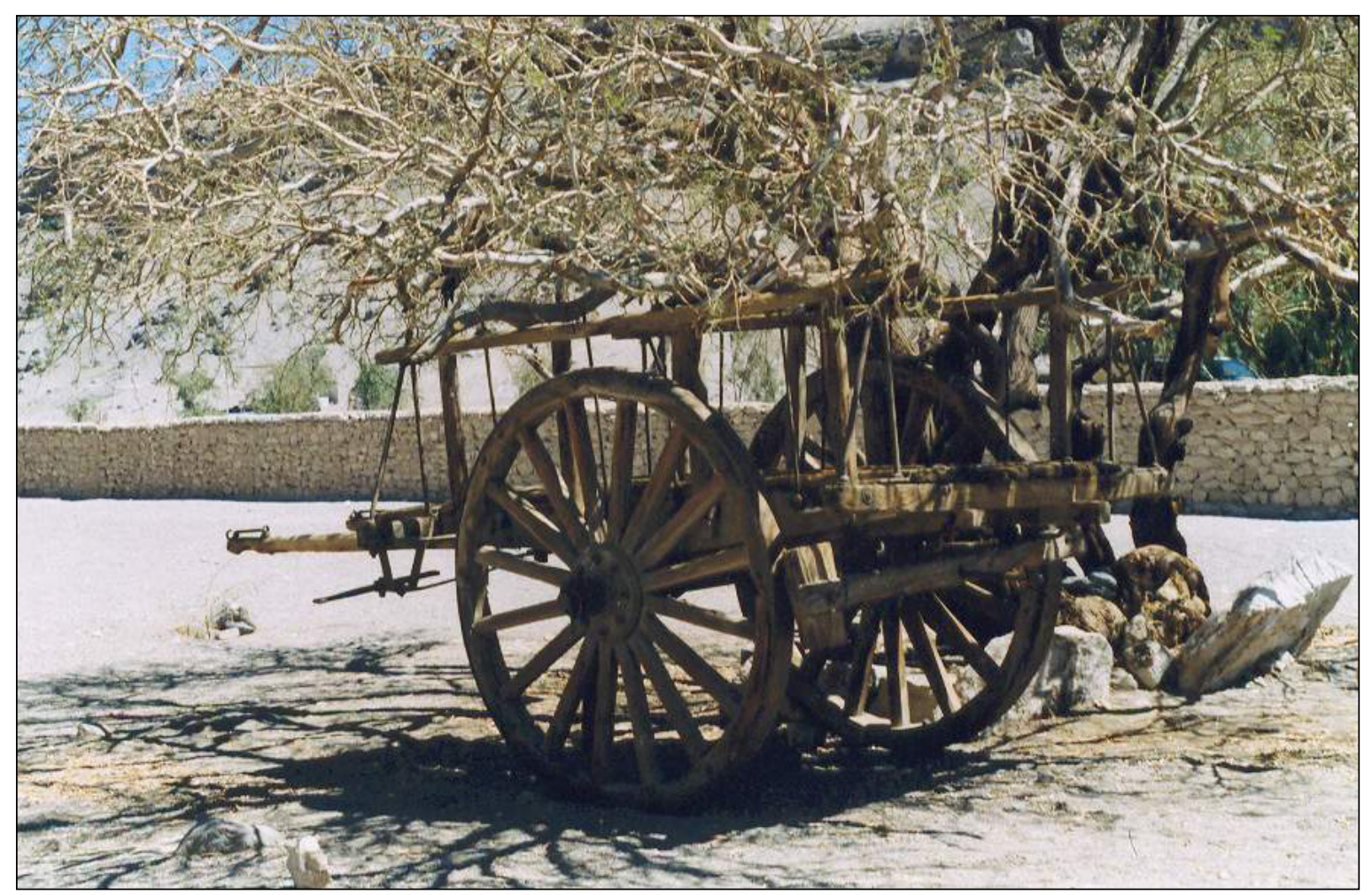

Figura 4. Carreta estacionada en el patio del Pucará de Lasana en 2005 (foto J. Berenguer).

1979: 327, 451). Por otra parte, no hay que olvidar que la localidad de Santa Bárbara está ubicada cerca de un angostamiento del valle de solo $3 \mathrm{~km}$ de ancho, accidente geográfico que desde tiempos prehispánicos estableció a este lugar como un punto estratégico para controlar la circulación por el valle (véase Berenguer 2004a: 214, 2004b: nota 11). Como resultado de toda esta situación, el movimiento de carretas y arrieros que vinculaba el litoral del Pacífico con el interior de Bolivia queda prácticamente paralizado (Bertrand 1885: 266), hasta el restablecimiento del libre tránsito, en 1885 , producto de la firma del Pacto de Tregua entre Chile y Bolivia el año anterior (Sanhueza y Gundermann 2007: 115, 2009: 225-228).

Durante el último tercio del siglo, las industrias del salitre en la pampa y del bórax en Ascotán dan lugar a una intensa circulación de carretas, que incluye el transporte de llareta (Azorella compacta) hacia los centros mineros para emplearla como combustible en el secado del mineral (Bertrand 1885: 65, 232). Los vehículos son descritos por Bertrand (1885: 266) como "carretones de dos rue- das" y provistos de toldo "tirados por cinco mulas colocadas en dos filas, la primera de dos mulas i la otra de tres" (Figura 4). A las más grandes y sólidas se les conocía como "huellas" y eran construidas especialmente para viajes largos y soportar fuertes pesos, tanto que contaban "con palancas para retener las ruedas en los declives de los caminos" (Arce 2004 [1930]: 280).

Localidades como Santa Bárbara, en tanto, siguen siendo usadas para engordar ganado mular y vacuno argentino en tránsito hacia Potosí, las salitreras o los campamentos mineros de Chuquicamata, Caracoles y El Abra. Entre fines del siglo XIX y mediados del XX, marcas como las de la Figura 5 estuvieron relacionadas con el tráfico de vacunos a Chile (Podestá et al. 2006: 184). No es el único lugar destinado a ese fin; también se emplean lugares cercanos a Santa Bárbara como Carrazona, La Laguna y Vizcachuno, cuyas vegas, por lo demás, habían sido usadas como zonas de pasturas para el ganado camélido desde por lo menos mediados del primer milenio de nuestra Era (Berenguer 1999: 12, 2004a: 221-25, 244).7

7 "Carrazona", como figura en la Carta "Estación San Pedro" del 


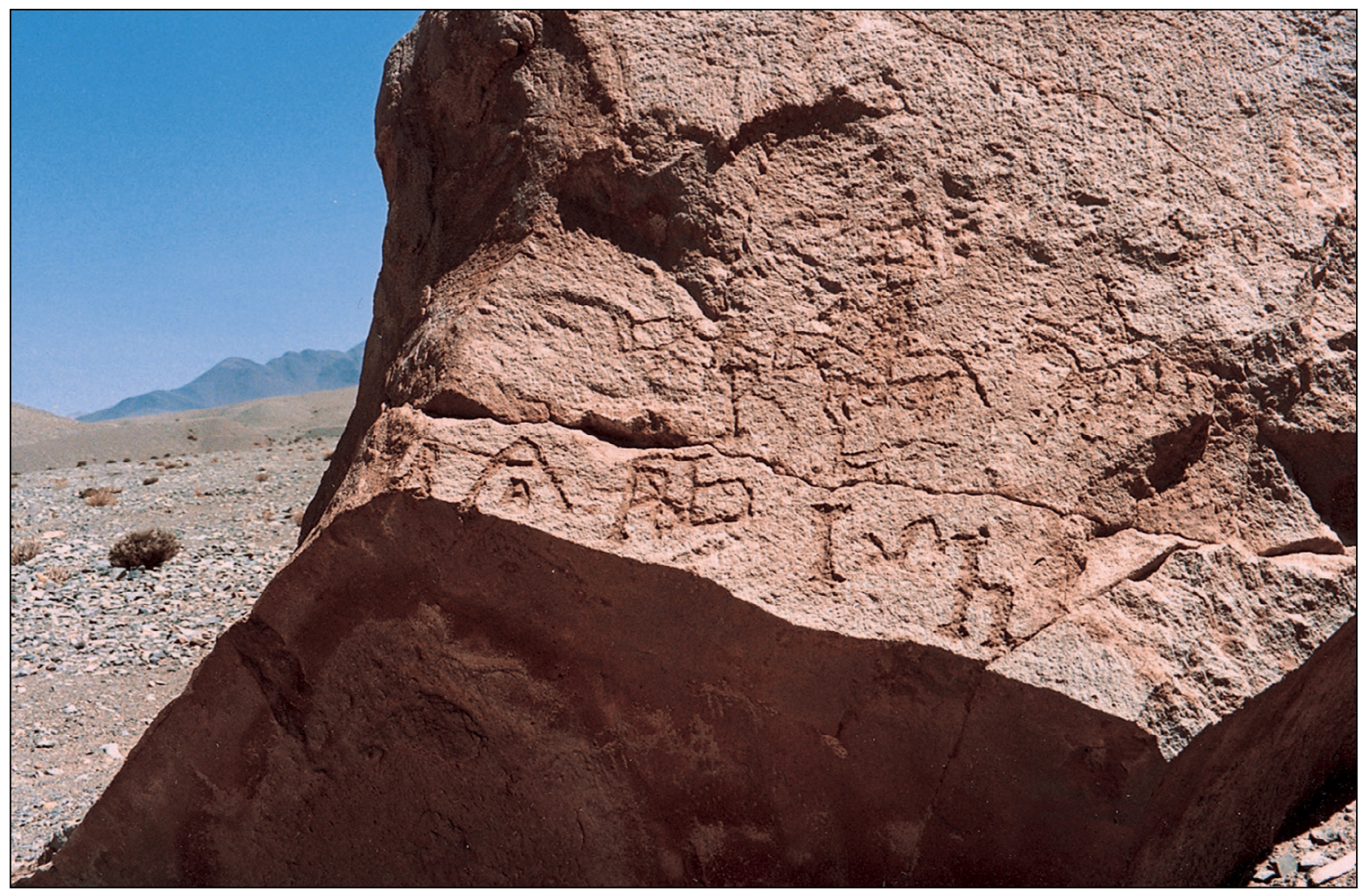

Figura 5. Representaciones de jinetes, iniciales de nombres y marcas de ganado grabadas en un bloque suelto de la quebrada de Quinchamale, cerca de la posta de Santa Bárbara (foto J. Berenguer).

En las postrimerías del siglo XIX, la inauguración del tramo Calama - Ascotán del Ferrocarril de Antofagasta a Bolivia (FCAB), cuya línea cruza el valle del Loa $4 \mathrm{~km}$ al sur de la posta de Santa Bárbara y $13 \mathrm{~km}$ al norte de Incaguasi, representa, al parecer, el comienzo del fin de la circulación de correos, acémilas, carretas y arrieros por el Alto Loa (Sanhueza y Gundermann 2009). Su trazado deja fuera a Chiu Chiu, que siempre había sido favorecido por el tráfico arriero y carretero, dañando su integración en los circuitos regionales y restándole protagonismo económico (Sanhueza y Gundermann 2007). La arriería, no obstante, es la más afectada ya que, al menos en estas rutas, no puede competir con el ferrocarril, disminuyen-

igm (2003), probablemente proviene de "Carrazana", que es el apellido de una acaudalada familia boliviana de Chiu Chiu que hizo su fortuna en los siglos XVIII y XIX. En la década de 1870, entre Fidel, Gregorio y Pedro Carrazana "sumaban 266 cuadras de alfalfa repartidas entre Chiu Chiu, Calama y Santa Bárbara; esto es, cerca del 20\% del total en ambas cuencas", seis de las cuales estaban en Santa Bárbara (Barros 2008: 128). Parte de estos últimos alfalfales seguramente estaban en la vega que hoy lleva su apellido. do la utilización de mulas, especialmente en la arriería indígena a larga distancia, persistiendo un tráfico local con burros y llamas (Sanhueza y Gundermann 2007: 116: 129-130). Este último tipo de circulación se mantuvo hasta muy recientemente, por ejemplo, entre Chiu Chiu, Lasana y Santa Bárbara (Gisoc 2009). En cuanto al tendido ferroviario a Conchi Viejo, éste se establece en 1906 (Thomson 2006), significando nuevas contracciones del tráfico arriero.

En la actualidad residen en el valle del Alto Loa unas pocas familias de pastores cuyos linajes poseen profundas raíces en la zona y siempre han reconocido a Conchi (hoy Conchi Viejo) como su centro ceremonial. De hecho, los restos de gran parte de sus ancestros reposan en el cementerio de esa aldea. Prácticamente deshabitada durante el año, Conchi Viejo se activa el 24 de junio (San Juan) y, principalmente, el 16 de julio ("La Tirana Chica"), fechas en las cuales emigrados y residentes del valle se reúnen en la aldea en fiestas religiosas de amplia convocatoria regional (Lindberg 1969; Villaseca 1998; 


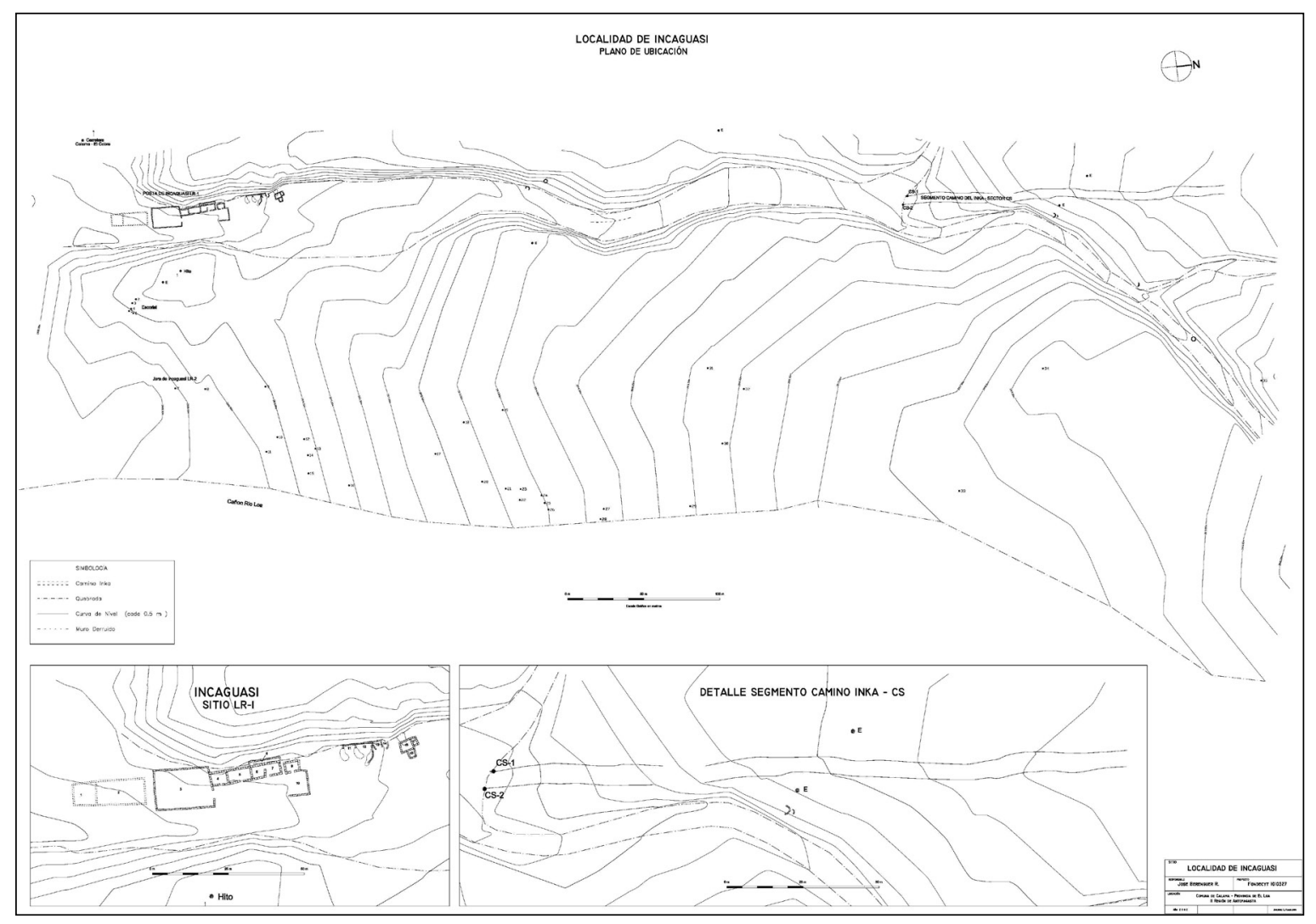

Figura 6. Plano general de ubicación de los sitios arqueológicos en la pampa de Incaguasi, incluido un segmento de camino inkaico.

Berenguer 2004a). ${ }^{8}$ Antiguamente la gente peregrinaba por huellas troperas, senderos, caminos de tierra yen tren; hoy lo hace por caminos en gran parte pavimentados, principalmente en bicicleta o en vehículos motorizados.

Cuáles de estos modos y eventos de circulación dejaron evidencias en el registro arqueológico de Incaguasi, es algo que exploraremos en las secciones que vienen a continuación. Antes, sin embargo, permítasenos describir la pampa de Incaguasi y los sitios arqueológicos relacionados con el tema de este artículo.

\section{* PAMPa de incaguasi Y LOS SITIOS LR-1 Y LR-2}

La porción de planicie occidental del Alto Loa que se extiende entre Lasana y la estación ferroviaria de Conchi tiene la forma aproximada de un triángulo isósceles, con su

8 Mayores antecedentes acerca de la historia cultural del Alto Loa, en Berenguer (2004a: 220-237). base más o menos a la altura de Lasana, uno de sus lados mayores limitado al oeste por pequeñas estribaciones de la Sierra del Medio, tales como Morros los Cerrillos, Morro Loa y Cerro Conchi, y el otro limitado al este por el borde del cañón del río. Despoblada y casi sin vegetación, esta desértica planicie de 2 a $5 \mathrm{~km}$ de ancho en la base y unos $25 \mathrm{~km}$ de longitud se desarrolla sin interrupciones hasta el cerro El Añil, punto donde, poco antes de la citada estación de ferrocarril y del Embalse de Conchi, dicha planicie se estrecha a solo $500 \mathrm{~m}$. Allí confluyen la línea férrea, la tubería de la aducción Lequena, la carretera pavimentada construida en los años noventa por Minera El Abra, el antiguo camino de tierra para vehículos motorizados, el camino inca y las ubicuas huellas troperas.

El relieve de esta planicie se presenta como una sucesión de afloramientos de rocas calizas de la Formación El Loa que sobresalen algunos metros del nivel general del terreno, este último compuesto de sedimentos aluviales recientes, principalmente arenas, gravas, arcillas y limos 
(Marinovic y Lahsen 1984). En uno de estos blanquecinos y sobreelevados afloramientos se encuentra la pampa de Incaguasi. ${ }^{9}$

Situada a unos $27 \mathrm{~km}$ al norte de Chiu Chiu, se accede a esta pampa por una huella vehicular que se desprende hacia el este de la carretera de Minera El Abra a la altura del kilómetro 60, corriendo con rumbo sureste hacia las ruinas del caserío (Astaburuaga Cienfuegos 1899) o posta de Incaguasi (Risopatrón 1924), sitio que hemos designado como LR-1 (Figura 6). ${ }^{10} \mathrm{Al}$ noreste, dominan el horizonte los volcanes San Pedro y Pablo, y al este el cerro Carcanal.

Una ancha huella tropera tipo "rastrillado" atraviesa la pampa en sentido norte-sur, mientras una angosta senda peatonal la cruza de poniente a oriente uniendo el Sitio LR-1 con la bajada al río. LR-1 se encuentra en línea con un segmento de camino arqueológico visible a unos 420

9 Incaguasi (del quechua "casa del Inka"), escrito a veces con las grafías Incahuasi, Inca-Huasi, Incahuasito, Ingahuasi, Ingaguasi o Ingaguases, es un topónimo que se repite en todo los Andes. Lo mismo ocurre en nuestro país: el Diccionario Jeográfico de Chile (Risopatrón 1924: 424-425, 427-428) incluye 16 entradas con este término, las que por supuesto no agotan la totalidad de lugares existentes con este nombre. Por ejemplo, en la propia zona del Alto Loa, aparte del Incaguasi que motiva este estudio, existe uno en el mineral de El Abra y otro en Bajada del Toro, entre Lequena y Taira, ambos de los cuales no figuran en este diccionario y tampoco en los mapas actuales. Con el fin de evitar confusiones entre sitios con el mismo nombre, a veces los arqueólogos o los editores de una publicación "indigenizan" la palabra (p.e., Inkawasi, véase Aldunate [2001a: 31]; también Stehberg [2001: 102]) y/o le agregan otro término a modo de "apellido" (Incahuasi-Inca [Adán 1999: 14, Figura1], Incahuasi-Risopatrón [Uribe y Cabello 2005 : 76], Incahuasi-Loa [Salazar y Borie 2013]), Inkawasi-Abra [Salazar et al. 2013]). En el caso del sitio Incaguasi referido en este artículo, optamos por conservar el término en solitario y mantener su grafía. Lo hacemos basados en dos criterios conjuntos: aquel derivado de su prelación en la literatura arqueológica del río Loa y aquel que otorga primacía a la forma en que el topónimo aparece escrito en la cartografía oficial, en este caso, en la Carta "Conchi" del IGM (2003).

10 "Ingaguasi. Caserío de pocos habitantes, situado en el departamento de Antofagasta á la inmediación de la margen derecha del Loa y á 18 kilómetros hacia el S. de la aldea de Conchi. El nombre es de la forma antigua de inca y de la voz quichua guasi, casa" (Astaburuaga Cienfuegos 1899: 333). "Incaguasi, $22^{\circ} 05^{\prime}, 68^{\circ} 38^{\prime}$ (posta abandonada). Se encuentra a $2898 \mathrm{~m}$ de altitud, en la márjen W del río Loa, a unos 18 kilómetros hacia el S del caserío de Conchi, en el camino a Chiuchiu i Calama" (Risopatrón 1924: 424). $\mathrm{m}$ al norte (véase Berenguer y Cáceres 2008a: 50, 53 y 56 , fotos de arriba, de abajo, de arriba izquierda, respectivamente), cuya traza desaparece al internarse por el seco y arenoso lecho de la quebradita y pasar frente al sitio, reapareciendo $580 \mathrm{~m}$ al sur (Berenguer et al. 2005). ${ }^{11} \mathrm{Es}-$ tos segmentos de camino son parte del Qhapaq Ñan o sistema vial de los incas en el Alto Loa, cuya traza solo vuelve a aparecer tanto al norte de la quebrada de Quinchamale en dirección al sitio Cerro Colorado, como en 12 trechos del recorrido de 19,36 km entre Incaguasi y Lasana, jalonados por cuatro sitios incaicos. Estos últimos incluyen ocho sayhuas en la pampa de Sandía, columnas de piedra que se ubican en ambos costados del camino inca. Inicialmente, Sanhueza (2005: 66; véase Berenguer y Cáceres 2008: 53, fotos de arriba e izquierda) las interpretó como parte de un sistema de demarcación de territorialidades (rituales, políticas, sociales) con "asociaciones simbólicas con el orden del cosmos, el espacio, el tiempo, los ciclos naturales y sociales", pero al profundizar su investigación, la autora las ha relacionado con solsticios y equinoccios, eventos astronómicos fundamentales en el calendario cusqueño o inca (Sanhueza 2012: 216 y ss, 241, 252, 258). En el caso de las sayhuas de Sandía (denominadas de Lasana por ella), están alineadas con la salida del sol el día del solsticio de invierno (Sanhueza 2012: 232).

\section{El Sitio LR-1}

Situado a una altitud de 2909 m, el Sitio LR-1 está a unos $180 \mathrm{~m}$ al oeste del borde del cañón, al interior de una quebrada somera de 24 a $30 \mathrm{~m}$ de ancho, que corta a través de un afloramiento de calizas, dejando a los lados dos escarpes de menos de $2 \mathrm{~m}$ de altura que protegen del viento (Figura 7). Se trata de un conjunto arquitectónico de más de un centenar de metros de largo, con una superficie edificada de unos $1000 \mathrm{~m}^{2}$. Consiste en 16 estructuras alineadas con la quebrada, varias de ellas con sus muros posteriores apegados al escarpe poniente y por lo general con sus vanos abiertos al este. En el plano los recintos 6 y 7 figuran como estructuras independientes, pero nuestras excavaciones comprobaron que el muro divisorio es

11 Referencias iniciales a este camino se encuentran en Cornejo (1995: 207; también Berenguer 1994b: 13 y Nota 7) y las primeras fotografías publicadas, en Stehberg (2001: 94 y 96). Para referencias más recientes, véase Berenguer et al. (2005: 9, 18-19, 23, 2829, Tabla 1 y Figs. 2c y 4a, c; Berenguer y Cáceres 2008: 49-52 ). 


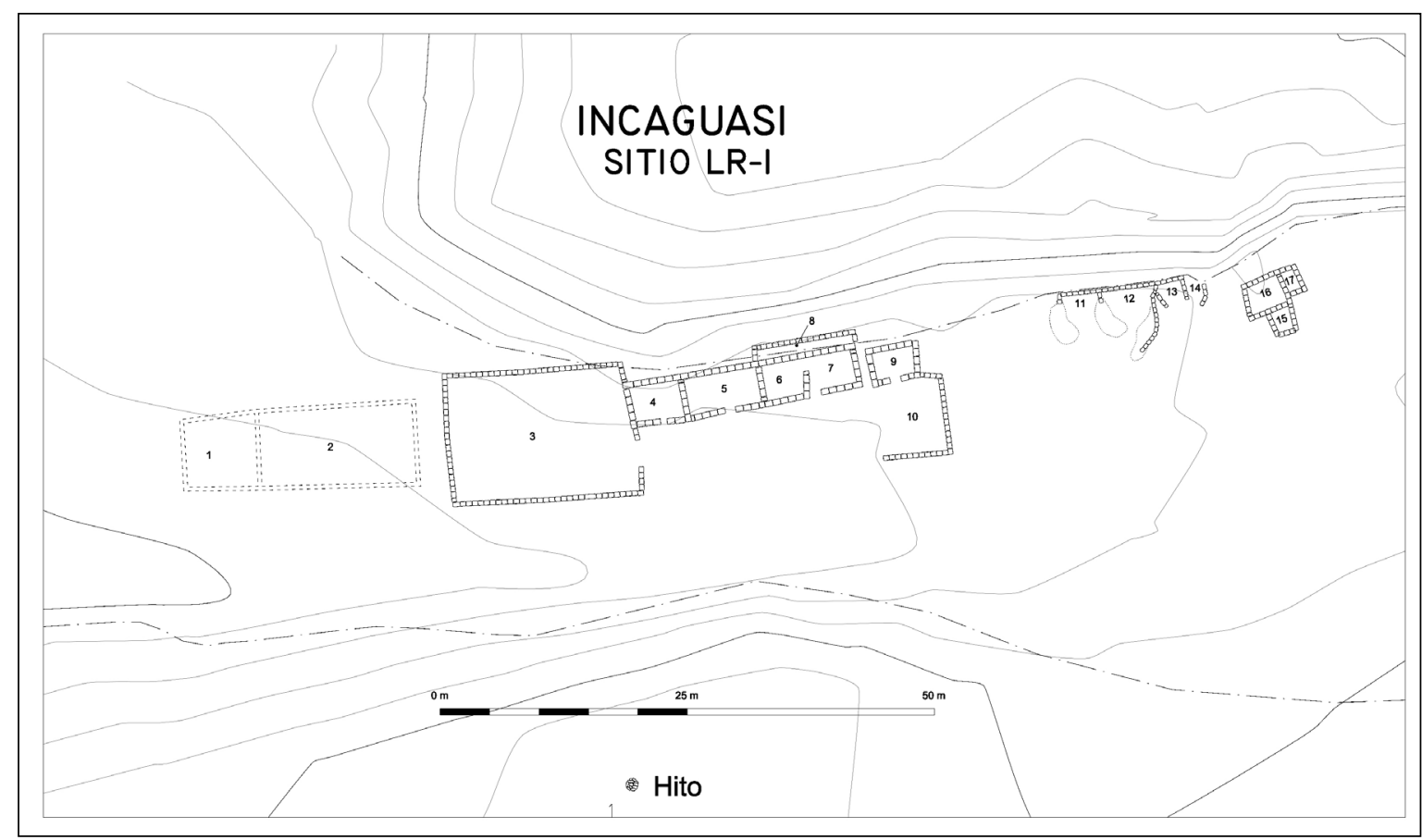

Figura 7. Plano de planta y numeración de las estructuras arquitectónicas del sitio LR-1, Incaguasi.

superficial y que se trata de un único recinto. Por eso, en dicho plano hay 17 estructuras y en este texto se habla de 16. En cuanto a la orientación de los vanos, en varios casos es solo una deducción nuestra, ya que por lo general se encuentran destruidos (Figura 8a).

La arquitectura de LR-1 fue construida con la misma roca del lugar. Varias estructuras exhiben muros ligeramente desaplomados, aparejo sedimentario, doble hilera de piedra con relleno y mampuestos relativamente trabajados (Figura 8b). ${ }^{12}$ La parte sur del sitio, denominada Sector I, presenta tres grandes recintos, dos de los cuales tienen sus muros casi completamente destruidos (Estructuras 1 y 2) y el tercero o Estructura 3, mayoritariamente en pie (Figura 9). El Sector II consiste en una hilera de cinco recintos contiguos más pequeños que los anteriores, de planta rectangular, todos con muros en parte en pie y en parte derrumbados (Estructuras 4, 5, 6/7, 8 y 9). Este sector presenta, además, los que parecen ser muros remanentes

12 Para una primera descripción de este sitio, véase Cornejo (1995: 207); y para la primera fotografía panorámica conocida, véase la toma aérea de F. Maldonado en Stehberg (2001: 102), aunque el encuadre muestra únicamente su Sector II. Otras tomas en Berenguer y Cáceres (2008: 50-51). de un sexto recinto (Estructura 10) de la cual se conservan una o dos hiladas. Finalmente, la parte norte o Sector III comprende siete estructuras (Estructuras 11 a 17), casi todas parcialmente cubiertas por la arena, con sus muros derrumbados o visibles solo en sus primeras hiladas.

Hubo dos temporadas de excavaciones. En la de 2002, se excavaron tres unidades: una unidad de 2 x $2 \mathrm{~m}$ apegada al muro oriental de la Estructura 3; una trinchera de $1 \mathrm{x}$ 1,58 m que atraviesa completa y perpendicularmente la Estructura 5 por su vano de acceso saliendo al exterior; $y$ una unidad de 1 x 2 m en la esquina noreste de la Estructura 9. Estas excavaciones procedieron por capas naturales. En la temporada de 2010 , se excavaron 13 unidades de sondeo de 0,50 x 0,50 m en las Estructuras 1, 2, 6/7, 9, 11, $12,13,15,16$ y 17. Todas las excavaciones de 2010 procedieron por capas naturales con niveles artificiales de $5 \mathrm{~cm}$.

De las 12 estructuras excavadas en LR-1, solo una evidenció depósitos exclusivamente prehispánicos; tres, depósitos solo históricos; cinco, depósitos tanto prehispánicos como históricos; y tres carecieron totalmente de depósitos culturales (Tabla 1). A continuación y en las siguientes secciones nos referiremos únicamente a las estructuras 


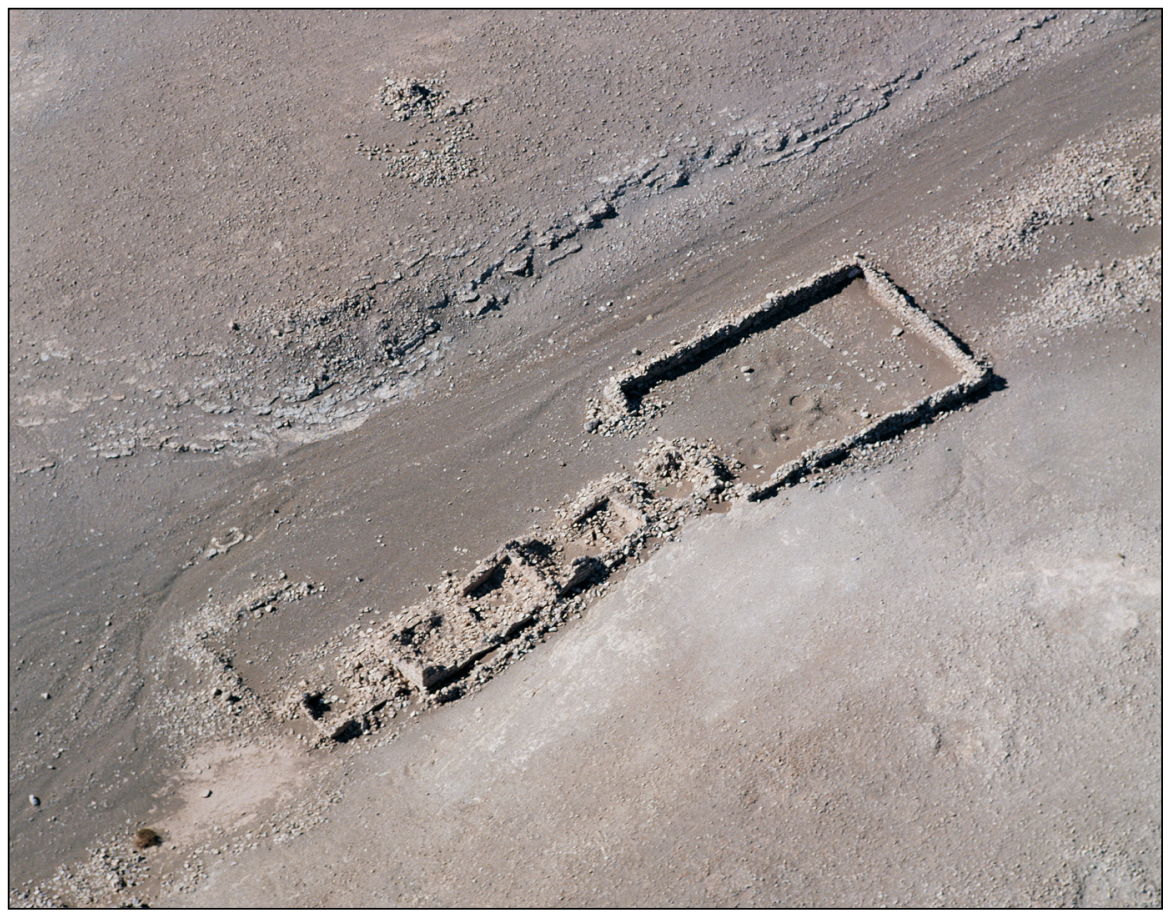

Figura 8a. Sitio LR-1 en el año 2000: Vista aérea del Sector II o Central del sitio.

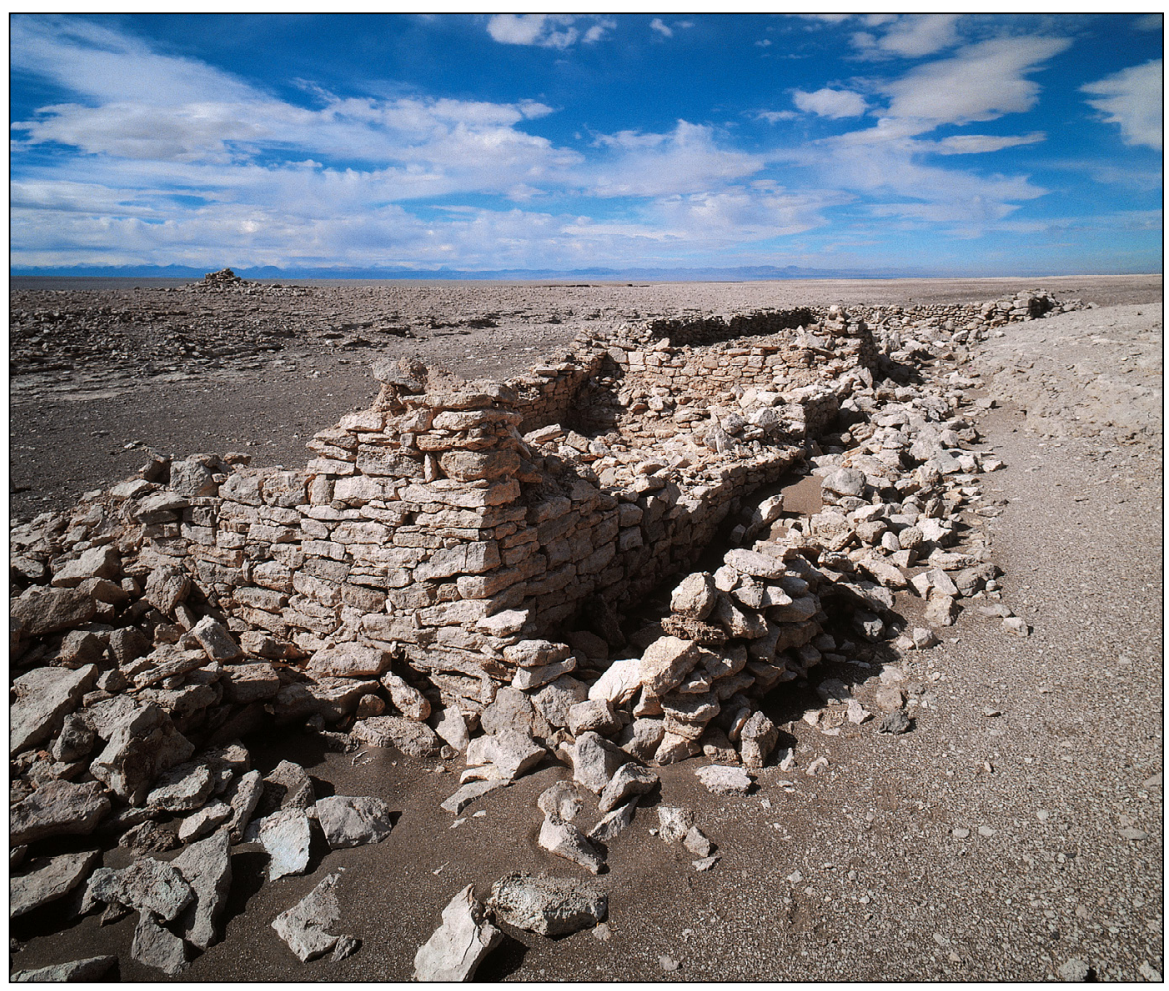

Figura 8b. Sitio LR-1 en el año 2000: En primer plano, la Estructura 6/7 vista desde el noroeste; detrás, al otro lado de la quebrada y sobre la pampa, el hito o Estructura i del sitio LR-2 (fotos F. Maldonado). 


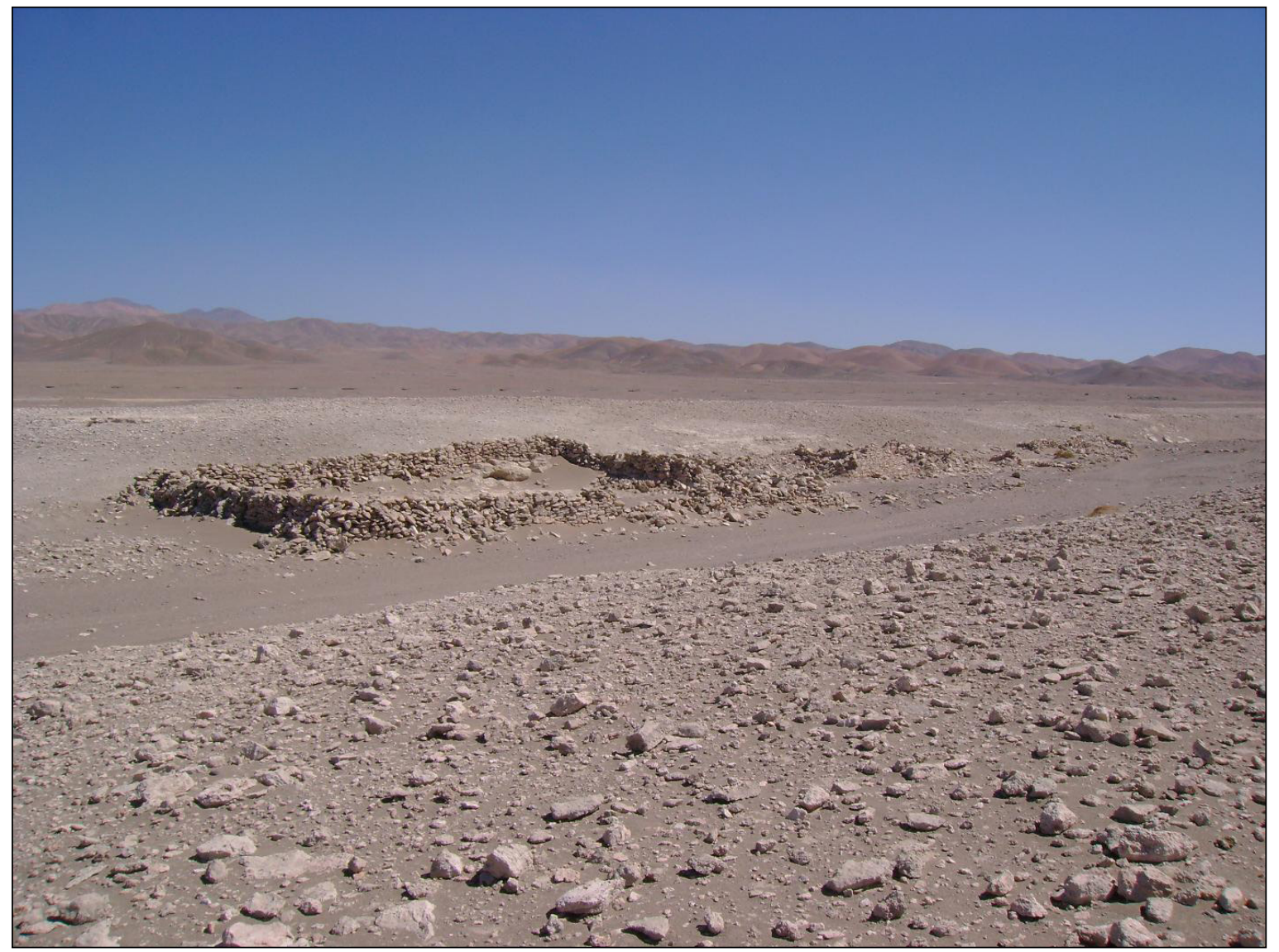

Figura 9. Vista de LR-1 y su Estructura 3 desde el sureste.

\begin{tabular}{|c|c|c|c|c|}
\hline Sitio & Estructura & Depósitos prehispánicos & Depósitos históricos & Sin depósitos culturales \\
\hline \multirow[t]{12}{*}{ LR-1 } & E-1 & & & $\mathrm{x}$ \\
\hline & E-2 & & & $\mathrm{x}$ \\
\hline & E-3 & $\mathrm{x}$ & $x$ & \\
\hline & E-5 & & $x$ & \\
\hline & E-6/7 & & $\mathrm{x}$ & \\
\hline & E-9 & $x$ & $x$ & \\
\hline & E-11 & $\mathrm{x}$ & & \\
\hline & E-12 & $\mathrm{x}$ & $\mathrm{x}$ & \\
\hline & $\mathrm{E}-13$ & $\mathrm{x}$ & $\mathrm{x}$ & \\
\hline & E-15 & & & $\mathrm{x}$ \\
\hline & E-16 & $x$ & $x$ & \\
\hline & E-17 & & $\mathrm{x}$ & \\
\hline \multirow[t]{2}{*}{ LR-2 } & E-3 & $\mathrm{x}$ & & \\
\hline & E-7 & $x$ & & \\
\hline
\end{tabular}

Tabla 1. Depósitos culturales en estructuras excavadas, sitios LR-1 y LR-2 


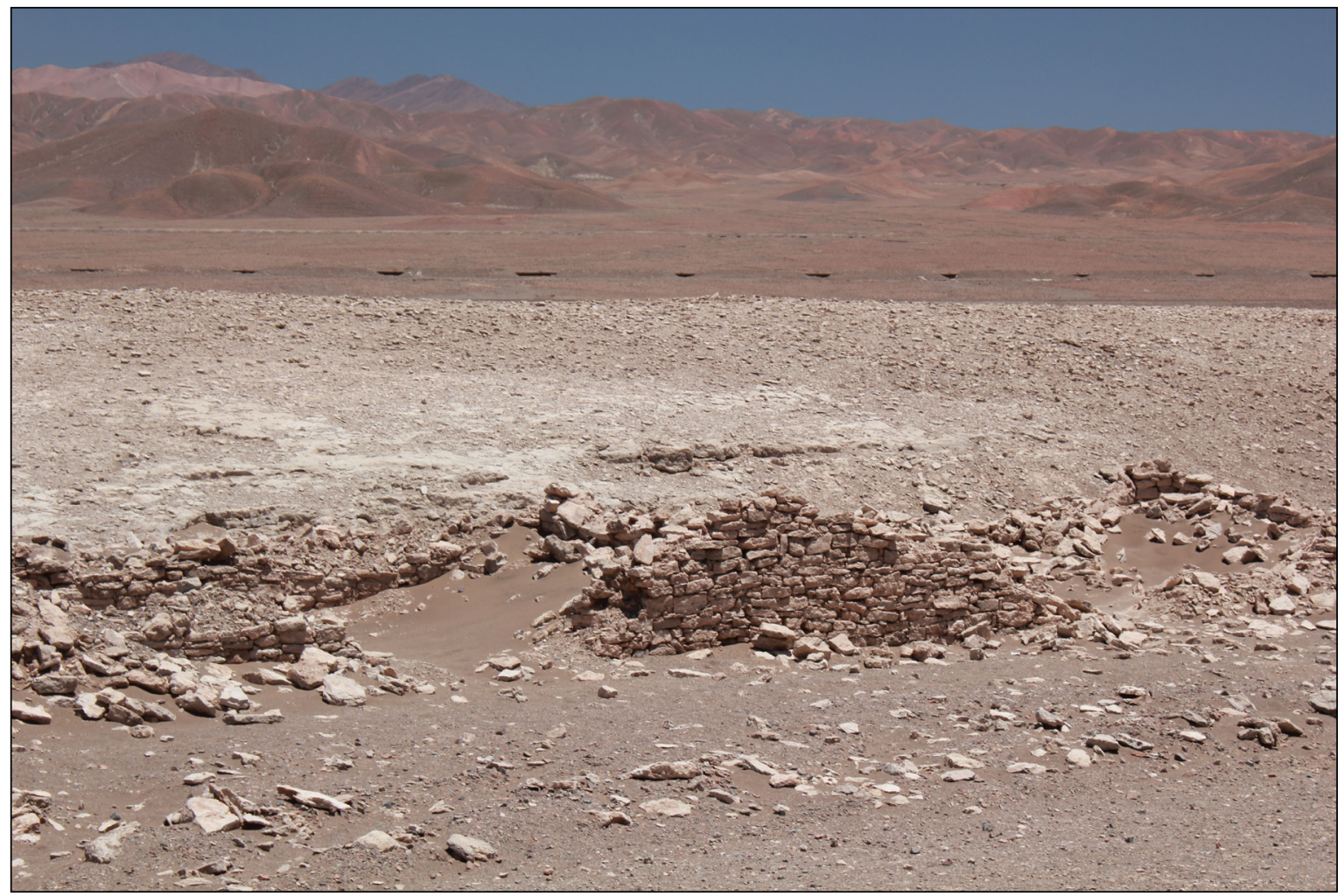

Figura 10. Sitio LR-1: Estructuras 5 y 6/7 vistas desde el este.

$3,5,6 / 7,9$ y 12 de este sitio, cuyos depósitos permiten seguir más claramente los principales hitos de la historia ocupacional de Incaguasi, así como los cambios funcionales experimentados por el lugar.

Estructura 3. Recinto rectangular de 14,00 x 19,60 m. Sus muros presentan en sus primeras hiladas aparejo sedimentario y doble hilera de piedras con relleno, y en su parte superior, aparejo rústico e hilera simple (pirca) casi intacto (Figura 9). A unos 4,90 m del muro sur, asoma la primera hilada de piedras o quizás los cimientos de un muro remanente de una estructura anterior hecho con doble hilera de piedras, de 9,47 $\mathrm{m}$ de largo y trazado paralelo a los muros más cortos del recinto. El paramento mejor terminado de la Estructura 3 es el norte, donde se aprecia un trabajo de desbaste de los mampuestos.

Estructura 5. Recinto rectangular de 8,70 x 5,00 m (Figura 10). Sus muros presentan aparejo sedimentario, doble hilera de piedras con relleno, utilización de cuñas de piedra para asentar los mampuestos, uso de mortero y posibles restos de enlucido de barro en las paredes interiores.
Presenta un banco de piedra (poyo) arrimado al muro sur y una banqueta adosada al muro oeste. En el tercio sur de la estructura y paralelo a los muros cortos del recinto se descubrió un muro más reciente de 2,00 m de largo, hecho con hilera simple o pirca en seco, del cual se conservan solo tres hiladas de piedras. El muro occidental y el oriental se encuentran severamente destruidos.

Estructura 6/7. Recinto rectangular de 9,40 ×3,64 m (Figura 10), que inicialmente fue numerado como dos estructuras diferentes debido a un muro pircado reciente que lo atraviesa en forma oblicua por el centro y que a la postre resultó ser superficial (véase supra). Los muros de la estructura están construidos con aparejo sedimentario, doble hilera de piedras con relleno, uso de mortero y posible aplicación de enlucido de barro. Presenta un banco de piedra (poyo) arrimado al muro sur. Los muros se encuentran severamente destruidos, en especial el oriental y el occidental.

Estructura 9. Recinto rectangular de 5,40 × 3,97 m, separado de la Estructura 6/7 por un pasillo de aproximadamente $0,60 \mathrm{~m}$ de ancho. Muros de aparejo sedimentario, 
doble hilera de piedras con relleno, trabajo de desbaste en los mampuestos y uso de mortero. Casi todos los muros se hallan derrumbados hacia el interior del recinto. Existe una estructura pircada semicircular en el interior, de data posiblemente posterior al resto del recinto ya que emplea piedras provenientes del derrumbe. Antes de la excavación, se encontró el componente pasivo de un yesquero de madera incrustado entre los mampuestos del muro oriental de esta estructura, a pocos centímetros de su esquina noreste. Dos dataciones de rasgos de esta estructura arrojaron $450 \pm 50 \mathrm{AP}(1420-1530 \mathrm{cal}$. DC) y $460 \pm 60$ $\mathrm{AP}$ (1400-1520 cal. DC).

Estructura 12. Recinto subrectangular muy destruido, de $3,72 \times 2,95 \mathrm{~m}$. Su muro oeste, que es el único más o menos visible, está apegado al escarpe de la quebrada y parece haber sido construido con aparejo sedimentario. Es posible que este recinto esté separado de la vecina Estructura 13 por un pasillo, pero el mal estado de conservación del muro norte impide afirmarlo con seguridad.

\section{El Sitio LR-2}

En el lado oriental de la pequeña quebrada somera, frente a LR-1, se abre una llana y pedregosa explanada natural que abarca alrededor de $75.000 \mathrm{~m} 2$. Contiene $35 \mathrm{acu}$ mulaciones de piedras, pequeños marcadores, semicírculos de piedra y otras estructuras dispersas, conjunto arqueológico que englobamos bajo la denominación de Sitio LR-2 (véase Figura 6). Sobre esta pampa, a 2910 msnm, unos $35 \mathrm{~m}$ al este del escarpe oriental de la citada quebradita y al sureste de un hito de piedras de forma cilíndrica que anuncia la localización del sitio a la distancia (Estructura 1), se hallan las Estructuras 2, 3, 4, 5 y 6, denotadas en el plano como "Escorial" y correspondientes a antiguas áreas de fundición de minerales. Se visualizan como oscuras manchas de escorias y piedras tiznadas sobre el color más claro de la pampa. En la Estructura 3 se trazó una trinchera de 1,0 × 0,5 m, procediéndose a excavarla mediante capas naturales y niveles artificiales de $5 \mathrm{~cm}$.
Estructura 3. Es una de las cinco manchas de escorias correspondientes a estructuras de fundición que hay sobre la pampa. Un material carbonizado recuperado de la Capa 1 dio una edad radiocarbónica de $730 \pm 30 \mathrm{AP}$. La capa corresponde a un depósito eólico deflacionado, en donde se encuentran aislados restos de carbón producto de las actividades pirometalúrgicas, así como escoria y minerales de cobre. Si bien no se han realizado a la fecha estudios antracológicos, las evidencias recuperadas y datadas indican el uso de carbón de leña en estas operaciones metalúrgicas. Es posible pensar en el uso de madera de chañar o algarrobo traída de lugares donde crecen estos árboles, que no son precisamente las inmediaciones del sitio.

Estructura 7. Localizada entre la Estructura 3 y el borde del cañón, a 2909,5 msnm, la Estructura 7 aparece como una concentración de piedras en forma de óvalo y ligeramente monticular, de unos $25 \times 20 \mathrm{~m}$, emplazada sobre un terreno levemente inclinado en sentido norte-sur (Figura 11). En superficie presenta gran cantidad de fragmentos de cerámica, trocitos de mineral de cobre, lascas y otros desechos líticos, concentrados principalmente en su sector sur. Se excavaron dos unidades: una de 1,50 x 3,25 m en lado sur de la cuadrícula B2 y otra de 0,75 x 2,10 en el lado norte de la misma. Las excavaciones procedieron exclusivamente por capas naturales.

Por último, importa señalar que en este punto de la explanada existe una empinada bajada al río por el talud de arena y escombros de falda que cae al cañón, el que aquí alcanza unos $65 \mathrm{~m}$ de profundidad y unos $230 \mathrm{~m}$ de ancho entre borde y borde, con una caja del río de 57 a $78 \mathrm{~m}$. Al empezar el descenso y debajo de las calizas se observan afloramientos de calcedonias e ignimbritas y un pequeño alero rocoso (LR-36). En el fondo del valle, el río serpentea flanqueado por angostas franjas de pastos y carrizos, principalmente matas de cola de zorro (Cortaderia atacamensis). No hemos determinado si en este punto el río presenta algún vado que permita cruzarlo. En todo caso, frente a esta bajada, pero en la planicie oriental, se observa una huella de edad desconocida que se dirige hacia la cuenca del río Salado. 


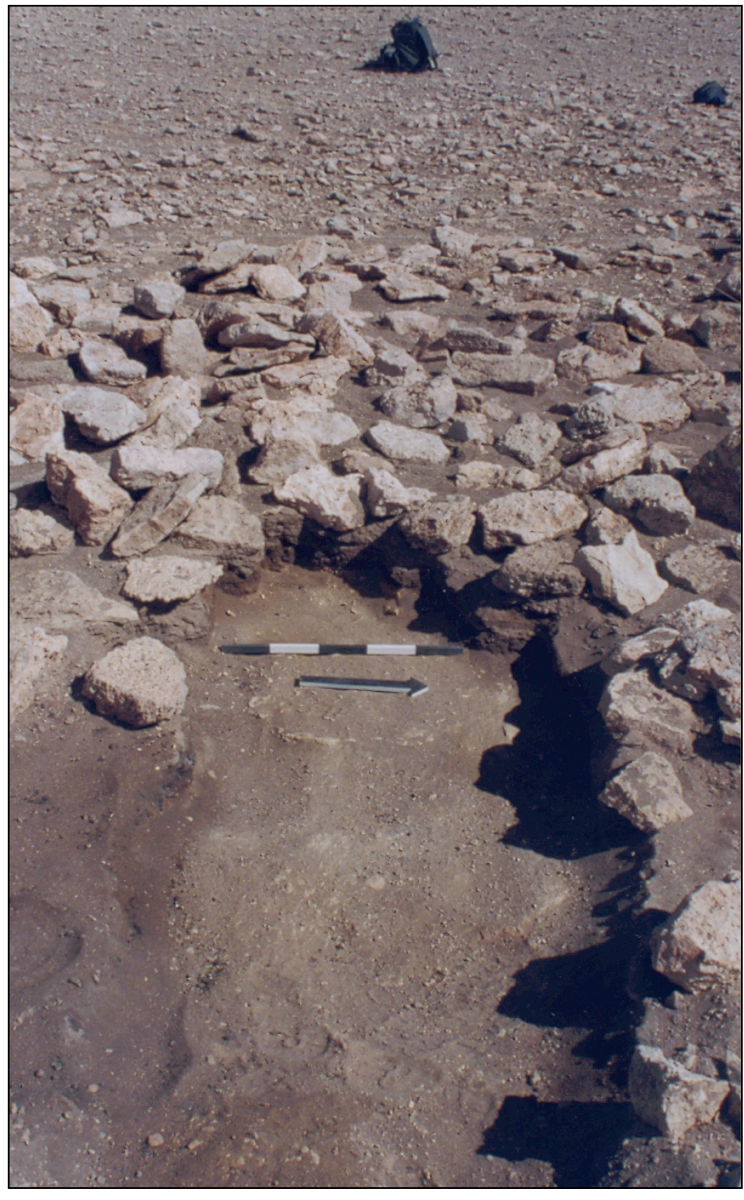

Figura 11a. Sitio LR-2: Excavación de la Estructura 7 del sitio LR-2.

\section{* El período intermedio tardío}

Las características ambientales de la pampa de Incaguasi y su posición estratégica dentro del tráfico regional explican por qué este sector ha carecido de ocupaciones humanas permanentes o semipermanentes a lo largo de toda su historia de uso y, en cambio, ha sido constantemente empleado como un lugar de apoyo a los diversos sistemas de tráfico implementados en la región en el transcurso del tiempo. Las diferencias entre estos sistemas explican en buena medida las diversas modalidades de ocupación y arquitecturización de los sitios LR-1 y LR-2.

En este contexto, nuestras investigaciones retrotraen la primera ocupación de la pampa de Incaguasi a, por lo menos, los primeros siglos del segundo milenio. Las evidencias provienen de material carbonizado extraí-

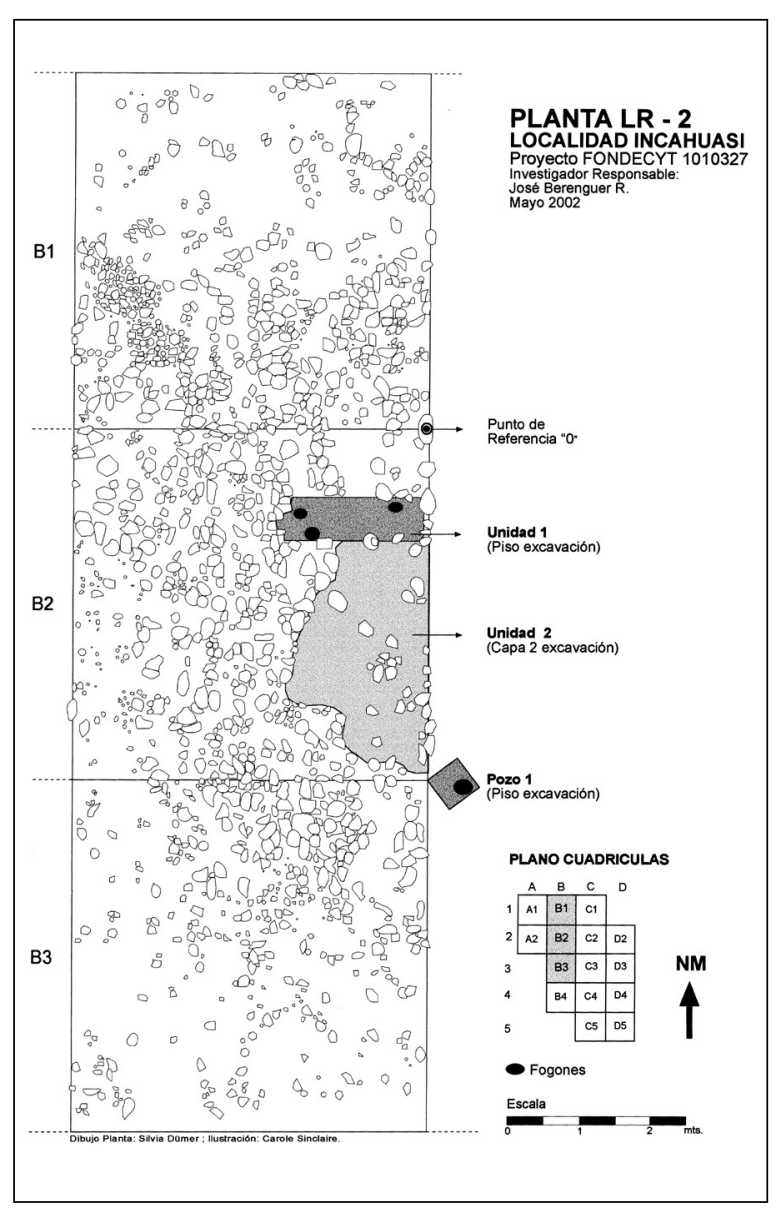

Figura ıb. Sitio LR-2: Plano de planta de la misma estructura.

do de la Estructura 3 del Sitio LR-2, que es una de las cinco áreas con escorias que acabamos de caracterizar como "estructuras de fundición". Se trata de mineral de cobre, probablemente fundido "al paso" aprovechando el fuerte viento que sopla en este punto, que es el más alto de la pampa. Una huella tropera ha sido detectada entre Conchi Viejo e Incaguasi (Salazar 2008; Corrales 2017), indicando un vínculo entre ambos lugares, el que pudo incluir el origen del mineral de cobre, ya que se ha documentado la presencia de minas de cobre correspondientes al Período Intermedio Tardío en las nacientes de la quebrada San Pedro de Conchi. Como ya señalamos, la única datación por ${ }^{14} \mathrm{C}$ disponible para el área de fundición de LR-2 proviene de la Estructura 3 y arrojó una edad de 730 30 AP (1273-1387 cal. DC), lapso que corresponde principalmente con Quinchamale I (ca.1200-1300 DC), una fase cultural del Sector Santa Bárbara que ha sido 
caracterizada, entre otras cosas, como de comienzos de la intensificación del tráfico de caravanas interregional por el Alto Loa, dentro de un contexto de auge de Chiu Chiu y la cuenca alta del río Salado, y de relativo estancamiento o declinación de la primacía regional de San Pedro de Atacama (Berenguer 2004a).

Como dice Angiorama (2006: 156), citando diversas fuentes, en los Andes Centro Sur, la combinación de pastoreo, minería y fundición de metales ha sido documentada en tiempos prehispánicos desde por lo menos el segundo milenio antes de nuestra Era, manteniéndose durante el período colonial y la época republicana, especialmente en Lípez. No obstante lo anterior, prácticas de metalurgia extractiva no han sido documentadas con frecuencia en los sitios de tráfico, ni en contextos etnográficos ni etnohistóricos. Arqueológicamente, existe al menos un caso similar al de Incaguasi, pero espacialmente aún más reducido, en el pequeño sitio de Esquiña, a la vera del camino inca del Alto Loa, a $16 \mathrm{~km}$ de las nacientes del río y a solo $800 \mathrm{~m}$ al norte de la quebrada de Chela (Berenguer y Cáceres 2008a). Hasta no contar con mayores antecedentes, es difícil por ahora comprender con mayor profundidad las prácticas metalúrgicas que los pastores-caravaneros u otros viajeros pudieron desarrollar durante sus travesías.

Gran parte del Sitio LR-2, el alero rocoso LR-36 de la bajada al río, y, acaso, el propio sitio donde más tarde se construyó LR-1, deben haber sido ocupados como lugares de pernocte por llameros y sus llamas cargueras. Distante $19,5 \mathrm{~km}$ al norte de Lasana, $18 \mathrm{~km}$ al sureste de Conchi Viejo y $18 \mathrm{~km}$ al sur de la posta de Santa Bárbara, que son los puntos más cercanos a LR-2, este sitio se encuentra a una distancia que se ajusta bien a la jornada promedio recorrida por una caravana de llamas (Berenguer 2004a: 54). La cerámica, de origen principalmente atacameño, sugiere que se trata de caravaneros que, desde los nodos de Lasana, Chiu Chiu o el Alto Salado, ocuparon la pampa de Incaguasi en sus trayectos caravánicos que conectaban la zona atacameña con el altiplano sur de Tarapacá y, posiblemente, la zona de Lípez. ${ }^{13}$ LR-2 debió constituir

13 Esta aseveración, sin embargo, requiere ser matizada, porque se sabe por Lozano Machuca (1992 [1581]) de la presencia en Lípez de indios "cimarrones" que, para llevar adelante "sus rescates", entran a Potosí haciéndose pasar por atacamas y a Atacama diciéndose tarapaqueños (Berenguer y Cáceres 2008b: 136-137). En un buen punto de descanso, dada su distancia respecto de otros nodos o sitios de enlace, su protección del viento y el hecho de que, bajando el cañón, los llameros disponían de pasto y agua para los animales. La leña para cocinar y calentar el ambiente, en cambio, deben haberla traído desde fuera, muy probablemente de Chiu Chiu, Lasana, Conchi Viejo o Santa Bárbara, aunque no puede descartarse que a veces la obtuvieran de los muy escasos arbustos presentes en los alrededores.

\section{$*$ EL PERÍODo INKA}

Las excavaciones en la Estructura 7 de LR-2 mostraron que la estructura es una versión arqueológica de las jaras, más conocidas en el norte de Chile como paskanas, campamentos caravaneros que han sido descritos con la primera de estas denominaciones por Nielsen (1997) en su etnoarqueología del caravaneo en Lípez. La concentración de piedras en forma de un arco abierto al este, son los restos derruidos de un sencillo parapeto semicircular de pirca seca donde habrían pernoctado conductores de recuas que hacían la ruta del Alto Loa. Los fogones en distintos puntos del interior y exterior de la estructura son característicos de este tipo de campamentos y responden a usos recurrentes de estas estructuras por diferentes expediciones de tráfico (Axel Nielsen, com. pers. 2001).

Las excavaciones revelaron una simple estratigrafía de cuatro capas que se extienden horizontal y homogéneamente a través de las unidades de excavación, y eventualmente, a través de toda la estructura. Desde la superficie hasta el suelo estéril el depósito alcanzó un espesor de 17 cm. La fecha de 1430-1660 DC y la presencia de cerámica incaica en las capas 1, 1-2 y 2, señalan que la Estructura 7 funcionó desde los inicios de la ocupación inca de LR-ı hasta bien avanzada la Colonia (véase infra). Esto significaría que el tráfico de llameros preincaicos descrito en la sección anterior siguió efectuándose por Incaguasi, tanto durante el Incario como después de él. Al final, las llamas serían paulatinamente reemplazadas por las mulas, proceso que según Sanhueza (1991) ocurre durante la segunda mitad del siglo XVII.

consecuencia y como bien apunta Nielsen (1997), cabe la posibilidad de que, como parte de su conducta o estrategia "camaleónica", esos caravaneros "cimarrones" no hayan usado cerámicas propias, sino de otros orígenes (Berenguer 2004a: 527). 
El análisis de los fragmentos cerámicos de superficie y de excavación corrobora que el Sitio LR-2 fue ocupado principalmente en tiempos prehispánicos, aunque siguió usándose en tiempos hispano-indígenas. A pesar de que la mayoría corresponde a vasijas cuya popularidad empieza en el Período Intermedio Tardío, la vinculación con el Tawantinsuyu queda establecida por la presencia de tipos Inca Local e Inca Provincial, incluyendo Yavi. La distribución horizontal de fragmentos de ambos períodos, observada tanto en la superficie como en la estratigrafía señalan que LR-2 y el vecino LR-1 habrían funcionado en conjunto y no siempre ni necesariamente en forma sucesiva, diferenciándose aunque al mismo tiempo complementándose por el carácter morfo-funcional de cada uno de ellos (Uribe y Cabello 2005). En este sentido, la alfarería del Intermedio Tardío representaría las funciones de preparación (tipo Turi Gris Alisado), almacenamiento (Turi Rojo Alisado y Turi Rojo Burdo) y consumo de alimentos (Ayquina, Dupont y Turi Rojo Pulido Interior o TRP). En tanto, las cerámicas incaicas destacarían la función de servicio y presentación de los mismos (Turi Rojo Alisado Exterior / Negro Alisado Interior o TRN y Yavi). La escasa presencia de indicadores de forma, las pocas huellas de uso y la baja restaurabilidad, así como el pequeño tamaño de los fragmentos sugiere que la cerámica proviene de desechos primarios, no habiendo propiamente basurales, circunstancia que acusa actividades pasajeras en el sitio.

La Estructura 7 del Sitio LR-2 (Figura 11a y b), con 156 piezas líticas y 967 fragmentos cerámicos funcionó como un lugar de pernocte de caravanas, a juzgar por su lítica expeditiva y oportunista, manufacturada sobre soportes principalmente de calcedonia provenientes de los afloramientos de las proximidades, así como por el ya mencionado bajo índice de ensamblaje de las piezas líticas y cerámicas (Uribe y Cabello 2005; Méndez 2007). También por la baja diversidad en las vasijas en términos de clases funcionales, lo que refleja un espectro de actividades muy limitado que es consistente con las de caravaneo (Nielsen 1997). Considerando la ausencia de basurales propiamente tales (solo basuras primarias), la presencia de fogones múltiples, el escaso espesor de los depósitos, los tipos cerámicos encontrados en el sitio y la gran cantidad de estructuras similares en sus alrededores, pensamos que en la Estructura 7 pernoctaron ca- ravaneros antes y durante la ocupación inca de LR-1 y que dicha estructura formó parte de la amplia zona de paskanas referida como Sitio LR-2 (Figura 6), comunicada por un sendero con las vegas del río Loa.

La adyacencia entre paskanas e instalaciones incaicas notada en Incaguasi es más o menos frecuente en el valle. De 14 paraderos de caravanas registrados en el Alto Loa, cinco están juntos o en localizaciones cercanas a asentamientos estatales (véase Berenguer et al. 2005: 25 y nota 9 para un caso fuera del valle). Puede agregarse el caso de Mal Paso, una paskana situada a medio camino entre el cerro Pabellón del Inca (Collahuasi) y Miño (Berenguer et al. 2011: 270). En algunos casos, probablemente se trata de sitios adyacentes de diferentes tiempos y en otros, como en Incaguasi, pueden haber funcionado en forma simultánea con la ocupación incaica. Dado esto último y puesto que por LR-2 pasa una huella tropera, es concebible que los incas hayan reservado el tráfico por el Qhapaq Ñan del Alto Loa únicamente para transeúntes y caravanas en misión oficial, consintiendo un tráfico tradicional o no estatal por vías paralelas a la arteria Inca (al respecto, véase Berenguer 2004b: nota 11; también Nielsen 2013). Estas vías serían anteriores a los incas y habrían seguido en actividad después de la caída del Tawantinsuyu, como se observa al norte de Incaguasi, donde una huella tropera corta el camino inca (véase Berenguer y Cáceres 2008a: 50, foto arriba derecha).

Las excavaciones en el Sitio LR-1, en tanto, comprobaron que las ruinas de Incaguasi, referidas como "caserío habitado" por Astaburuaga Cienfuegos (1899) y como "posta abandonada" por Risopatrón (1924), no corresponden a un asentamiento de data puramente histórica como se desprendía de esas menciones y de otros antecedentes, tales como el ya mencionado Mapa del teatro de la guerra de Raimondi (1879). Quedó estratigráficamente demostrado que el conjunto fue construido desde sus cimientos durante la época inca, idea que hace 15 a 20 años se basaba exclusivamente en la arquitectura visible y en los fragmentos cerámicos hallados en superficie (Cornejo 1995; 2001a). La Estructura 3, por ejemplo, presentó lo que interpretamos como el muro remanente sur de un gran recinto subyacente, al que pertenecerían también los muros de la Estructura 10. Seguramente, la Capa 3 de la Estructura 3 es la capa ocupacional de ese recinto vestigial, cuyos remanentes deben haber formado parte 
de un rectángulo perimetral compuesto o RPC incaico que fue modificado en tiempos históricos para darle otras funciones. La fotografía de la Figura 8a apoya esta interpretación arquitectónica.

Las mejores pruebas de ocupación incaica en LR-1 provienen de las Estructuras 9 y 12. La excavación de la Estructura 9 (Figura 12a) mostró que su primera ocupación ocurrió durante el Horizonte Tardío, ya que las fechas para material carbonizado de fogones de esta ocupación inicial (rasgos 5 y 2) son de $450 \pm 50 \mathrm{AP}(1419-1626 \mathrm{cal}$. DC) y de $460 \pm 60$ AP (1409-1627 cal. DC), o sea, contemporáneas con el Período Inka (Berenguer 2007: 42-427). Mostró también que los responsables de su construcción fueron agentes del Tawantinsuyu, pues ciertas prácticas rituales identificadas en el recinto son de afiliación incaica. Nos referimos al entierro y sellado mediante la Capa 3 de cerámica Diaguita Inca (originaria del Norte Chico de Chile) a modo de ofrenda en la esquina de la Estructura 9 (Figura 12b), evento que ha sido interpretado como un acto de fundación del recinto, y quizás, de todo el asentamiento (Uribe y Cabello 2005: 93-94). Prácticas dedicatorias de consagración de edificios, tales como las "sepulturas en las esquinas de las casas", estaban en la lista de wak'as o "cosas sagradas" de los incas (Garcilaso de la Vega (1943 [1609]: 72), y han sido registradas en sitios importantes de esta región, como

LR-1, Estructura 9, Unidad, Capa 3 (base). PLANTA

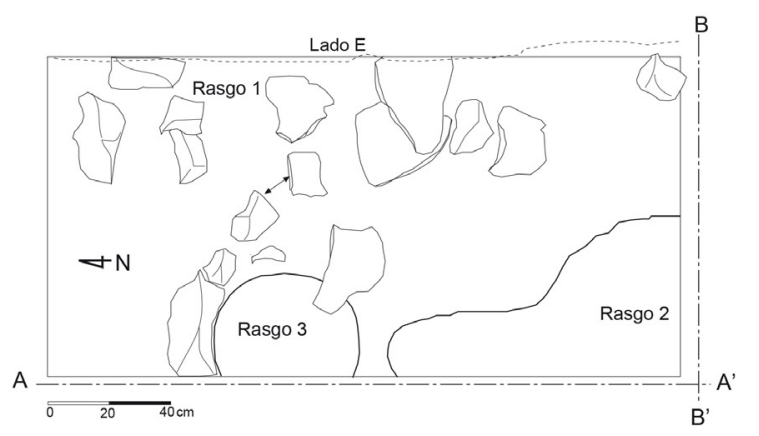

LR-1, Estructura 9, Unidad I. PERFIL OESTE, Corte A-A'

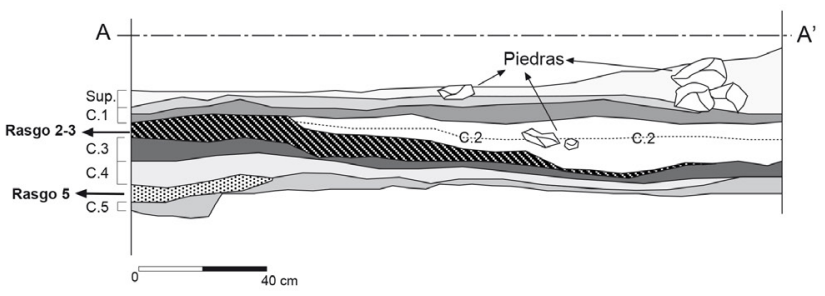

LR-1, Estructura 9, Unidad I. PERFIL SUR, Corte B-B'

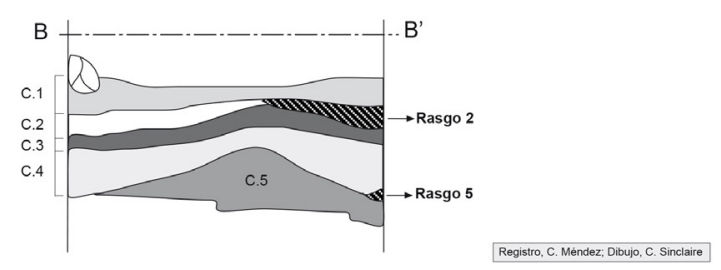

Figura 12a. Sitio LR-1: Corte estratigráfico de la estructura 9 de LR-1. 


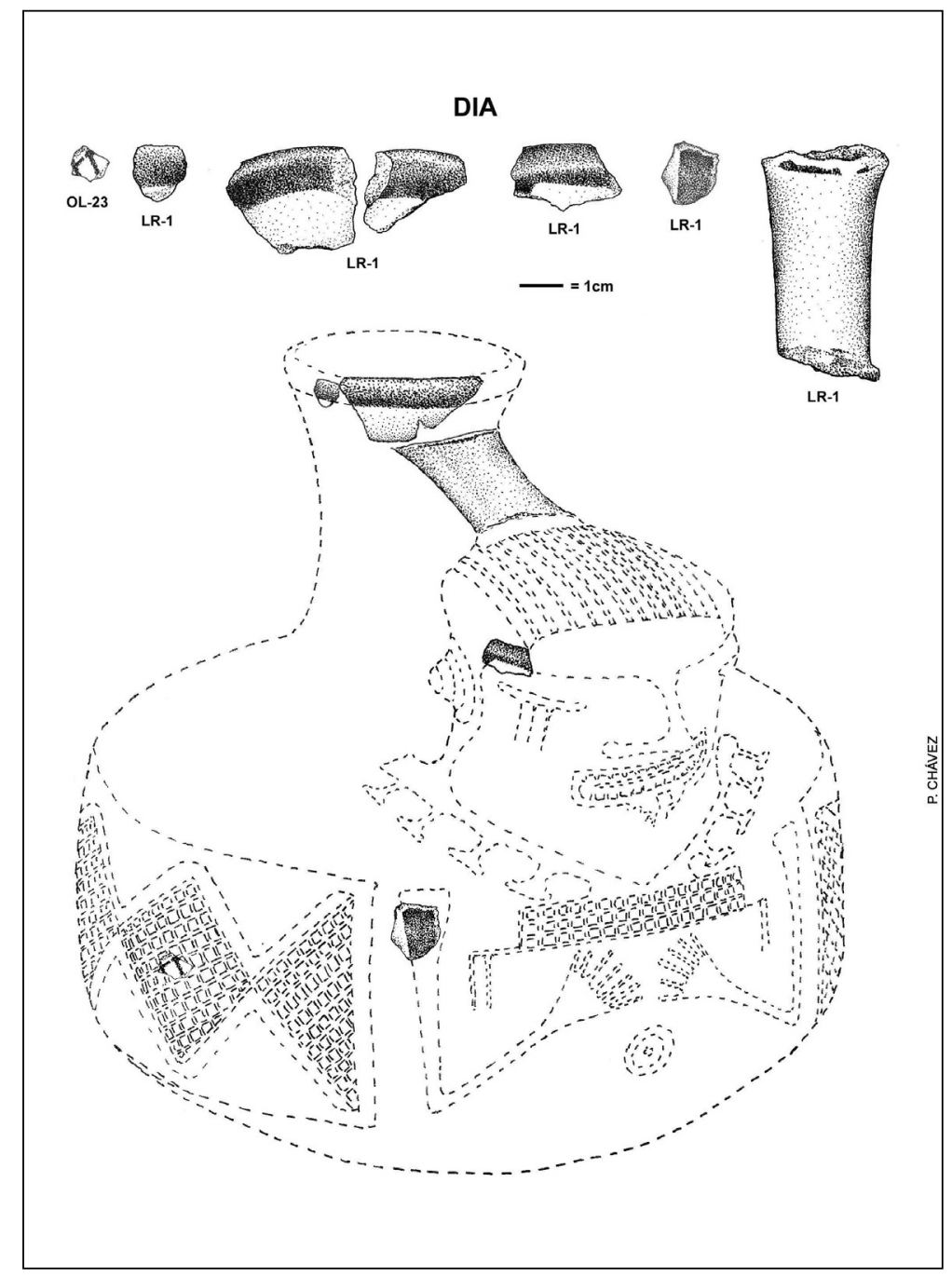

Figura 12b. Fragmentos de un jarro-pato Diaguita Inka encontrados en la esquina noreste de esta estructura.

Turi, distante de Incaguasi poco más de $39 \mathrm{~km}$ al sureste en línea recta (Aldunate 2001b; Berenguer y Salazar 2017).

La Capa 4 de la Estructura 12 de LR-1, en tanto, fechada en $430 \pm_{40} \mathrm{AP}(1439-1626 \mathrm{cal}$. DC), corresponde al depósito cultural dejado por los primeros ocupantes de este recinto. Su adscripción al Horizonte Tardío está dada conjuntamente por esta datación y por el hallazgo de una cabeza ornitomorfa de un plato de cerámica de tipo Inka Local Turi Rojo Revestido Pulido Ambas Caras (Salazar y Borie 2013). Destacamos el hallazgo de semillas de chañar y algarrobo en ambas estructuras, porque demuestra que hubo circulación desde oasis más bajos como Lasana, Chiu Chiu, Calama o Quillagua, ya que ese es el am- biente más propicio para el crecimiento de esos árboles.

En síntesis: aunque la pampa de Incaguasi fue usada como zona de paskana desde a lo menos $1200 \mathrm{DC}$, en algún momento del siglo XV los incas construyeron allí una instalación enteramente nueva, lo cual muestra un cambio importante en el sistema de circulación por la zona y, evidentemente, en la función del sitio LR-1. Esta instalación es parte de otras 11 que jalonan la ruta estatal entre Collahuasi y Lasana-Chiu Chiu (Berenguer et al. 2005; Berenguer 2007; Berenguer et al. 2011). El lugar proporcionaba pasturas, agua, comida y albergue para individuos en tránsito. El coirón o paja brava, que puede haber formado parte de la techumbre de los re- 
cintos, debe haber sido traído desde zonas más altas. En cambio el carrizo, que suele combinarse con la paja en este tipo de cubiertas, está disponible en el río. El lugar parece haber funcionado como un importante nudo vial, ya que viniendo de Chiu Chiu o Lasana, era poco después de Incaguasi donde el camino se dividía en una vía que conducía a las minas incaicas de Conchi Viejo y El Abra (Salazar 2008, Salazar et al. 2013; Corrales 2017), y otra que se dirigía al norte en dirección a sitios incaicos como Cerro Colorado y en último término a Miño y Collahuasi (Berenguer 2007; Berenguer et al. 2011). Al comparar el tamaño y la complejidad de la instalación incaica de Incaguasi (LR-1) con otros sitios del Alto Loa y de la región, es claro que representa una categoría intermedia de asentamiento entre sitios grandes (para los estándares del valle), como Cerro Colorado y Miño, con más de 30 estructuras, espacios públicos y arquitectura incaica, y sitios chicos de una sola estructura, como Todos los Santos, Esquiña y Mal Paso, que perfectamente podrían caer dentro de la categoría de chaskiwasi. De ahí que reservemos para Incaguasi la designación de "tambillo". No obstante lo anterior, su relativamente mayor tamaño y complejidad en comparación con el resto de los asentamientos de enlace que no presentan espacios ceremoniales formales (plazas), pudo deberse a su rol central en el abastecimiento y la comunicación entre las explotaciones mineras incaicas de El Abra y Conchi, los nodos agropastoriles del Loa Medio y, eventualmente, aquellos de la cuenca alta del río Salado.

\section{• El período colonial}

Las excavaciones no recuperaron materiales claramente asignables a los siglos de la Colonia, probablemente debido más a limitaciones de nuestra estrategia de investigación que a una discontinuidad objetiva en la secuencia ocupacional de estos sitios. Como ha dicho Smith (2008) en otro contexto, la ausencia de evidencia no es necesariamente evidencia de ausencia. De hecho, los contextos fechados en el sitio corresponden a la base de la ocupación de las estructuras 7 y 12, habiéndose detectado diversas capas sobre estos depósitos, algunas de las cuales presentaron fragmentos del tipo alfarero Turi Café Alisado, correspondiente a momentos coloniales de la región (Varela et al. 1993). Por lo demás, los extremos más recientes de varias de las fechas calibradas caen en las primeras décadas del siglo XVII. En consecuencia, es casi seguro que después de que el lugar fue abandonado por los incas, la pampa y lo que quedó del tambillo fueron ocupados nuevamente como paskanas, tanto por el caravaneo tradicional como por el creciente tráfico mercantil. En todo caso, es presumible que con la paulatina sustitución de la llama por la mula como bestia de carga a partir del siglo XVII, la detención nocturna en Incaguasi haya ido perdiendo justificación para quienes hacían la ruta entre Chiu Chiu y Santa Bárbara, toda vez que la distancia diaria posible de recorrer por la mula es muy superior a la de la llama. Lo más probable es que desde entonces la función del lugar haya cambiado a la de punto de descanso a media jornada de viaje entre esas dos localidades. Algo así como una parada para tomarse un respiro, servirse un tentempié y proseguir la marcha. Con todo, la ocupación colonial es uno de los aspectos menos conocidos de la pampa de Incaguasi y se requerirá más investigación para caracterizarla con suficiente detalle. Lo mismo puede decirse del conocimiento sobre el tráfico de recuas de llamas de esta época.

\section{* El período boliviano}

De las ocho estructuras de LR-1 que contenían depósitos históricos (Tabla 1), la Estructura 5 (Figura 13) fue la que brindó más información sobre este período, en especial sobre el siglo XIX, asunto que abordaremos enseguida.

La trinchera excavada en esta estructura reveló cinco capas (considerando la capa superficial [cultural], las capas 1, 2a-b y 3 [todas culturales], y la Capa 4 [estéril y correspondiente al suelo natural de la quebrada]). La explicación más plausible para la ausencia de materiales prehispánicos en las excavaciones de esta estructura arquitectónicamente tan incaica, es que, antes de usarla, sus ocupantes históricos la hayan limpiado prolijamente. Una importante clave para construir una cronología relativa de esta estructura se halla en los Rasgos 2 y 3 de la estratigrafía de la trinchera. Se trata de unos lentes de tierra quemada y carbones, que por su extensión horizontal en la trinchera de 2002, su presencia en un pozo de sondeo excavado en la misma estructura en 2001 y su aparición con iguales características en las excavaciones de 2010 en la contigua Estructura 6/7, interpretamos como los restos del incendio que según la documentación histórica 


\section{LR-1, Estructura 5, Unidad 1, Perfiles}

PERFIL SUR - Unidad 1

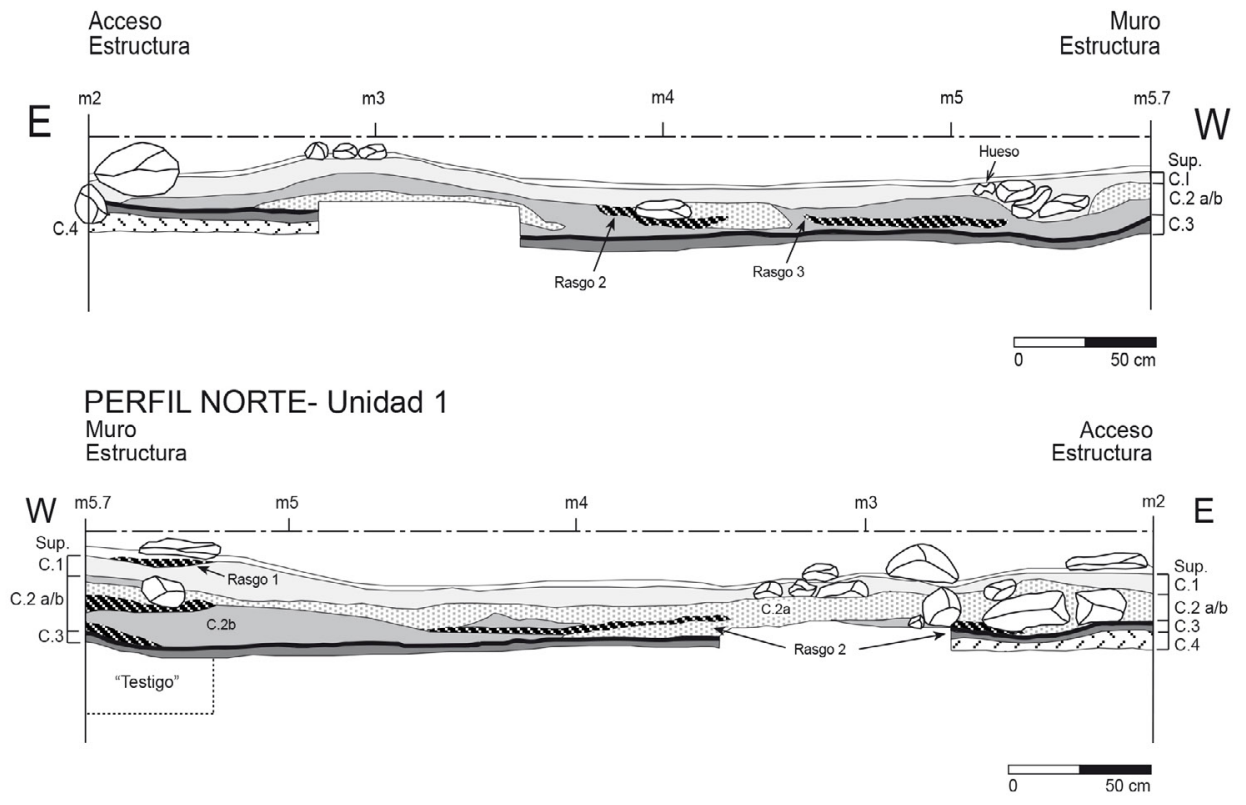

PERFIL OESTE - Unidad 1

PERFIL ESTE - Unidad 1
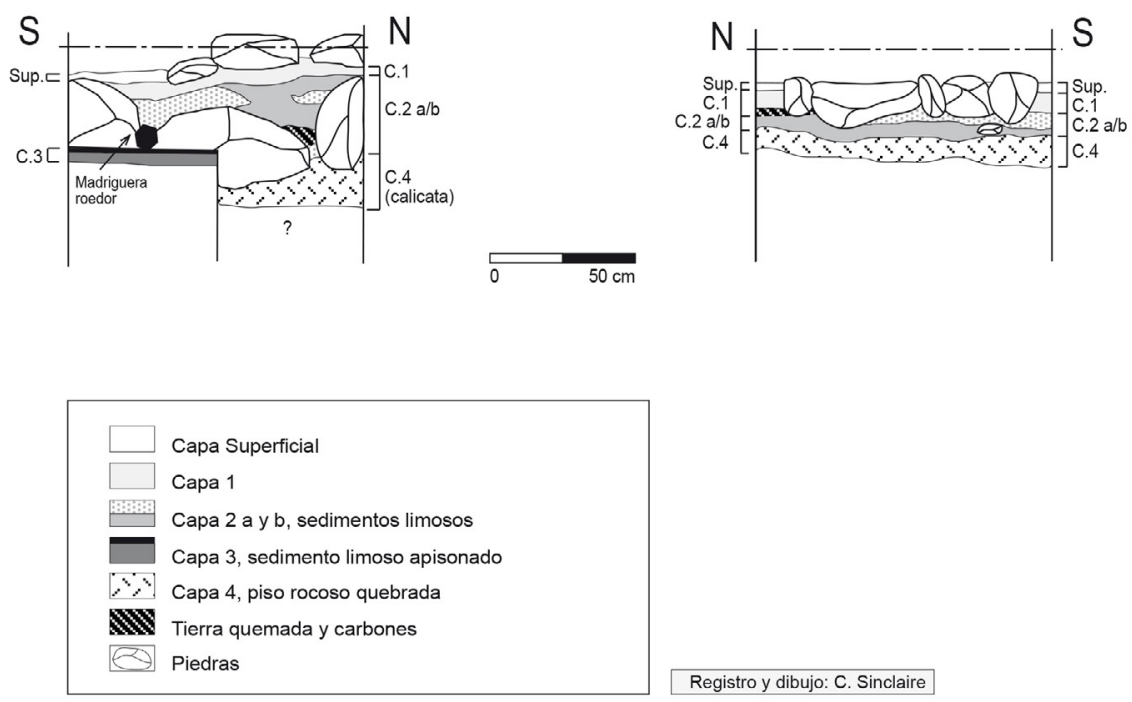

Registro y dibujo: C. Sinclaire

Figura 13. Sitio LR-1: Corte estratigráfico en la Estructura 5. 
habría afectado a Incaguasi en $1841 .{ }^{14}$ En el pozo excavado en $6 / 7$ aparecieron siete capas, las tres inferiores estériles. Sobre la Capa 4, que es de tiempos históricos, están las siguientes: la Capa 3 c correspondiente a coirón parcialmente quemado, el Rasgo 2 que es tierra quemada y con carbones, y la Capa za que consiste en coirón dispuesto en distintas direcciones y muy compactado, y encima palitos más gruesos de carrizo dispuestos en diagonal (Figura 14). Interpretamos estos hallazgos como la techumbre parcialmente consumida por el fuego del incendio mencionado por Cajías, la que habría colapsado sobre el piso del recinto.

De ser correcta esta interpretación, los restos del siniestro en la Estructura 5 fijarían un terminus ante quem (sensu Barker 1977) para todo lo que está depositado debajo de ese estrato. O sea, la Capa 2b, sobre la que se depositan estos lentes de $\mathrm{R}_{2}$ y $\mathrm{R}_{3}$, no podría ser más reciente que el mes de abril de 1841. Obviamente, este mismo evento fija un terminus post quem para todo lo que se encuentra encima de estos rasgos y que necesariamente dataría de una fecha posterior al incendio.

Esta misma estratigrafía proporciona otra clave para seguir calendarizando las ocupaciones de la Estructura 5. En la Capa 2 a -aquella que sobreyace a los rasgos del incendio ( $\mathrm{R}_{2}$ y $\mathrm{R}_{3}$ ) - fueron encontrados varios fragmentos de etiquetas de papel de algún producto no identificado, uno de los cuales presenta la siguiente leyenda: "187 ESPOSIC INTERNACIONAL" (Figura 15). ${ }^{15}$ Suponemos que la cifra corresponde a algún año de la década de 1870 al que se le ha borrado el último dígito. La palabra "Esposic", en tanto, puede referirse a una exposición celebrada en esa década en un país de habla castellana. Lo más probable es que se trate de la Exposición Internacional de Santiago, organizada en el Parque Quinta Normal de esa ciudad entre el 16 de septiembre de 1875 y el 16 de enero de 1876 , a la que acudieron como expositores diversos

$14 \mathrm{Al}$ respecto, dice Cajías (1975: 91): "Para colmo de males, se incendió en abril de ese año [1841] la posta de Ingahuasi, el causante 'ya sea de intento o por descuido' logró embarcarse en el mismo puerto porque la acusación contra él del corregidor de Calama llegó después".

15 El papel de las etiquetas estaba en tan malas condiciones de preservación, que se desintegró en el momento de extraerlo del suelo. Afortunadamente, se logró hacer un croquis in situ de sus imágenes y leyendas. países, entre ellos Perú y Bolivia. Nuevamente tendríamos aquí un hallazgo que fijaría un terminus ante quem para todo lo que está depositado debajo de la Capa 1 y un terminus post quem para la Capa Superficial y el derrumbe que se encuentra encima.

Admitimos que esta evidencia no es tan precisa ni contundente como la del incendio de 1841, pero hay otros datos que contribuyen a ajustar un poco más la cronología. Nos referimos a la probable relación causal entre el ya citado gran terremoto del 9 de mayo de 1877 y el colapso del muro oriental de la Estructura 5 de LR-1, algunas de cuyas piedras cayeron en lo que después se constituiría en nuestra Capa Superficial (véase Figura 13). Citando a Francisco Vidal Gormaz, Montessus de Ballore (1912: $165,185)$ recuerda los efectos de este gran terremoto en Chiu Chiu y alrededores:

Chiu-Chiu.- Según testimonios verbales que en diciembre de 1909 el autor pudo recoger de algunos moradores ancianos, entonces radicados en Calama, aquel lugarejo [Chiu Chiu] habría sido completamente arruinado. La torre de la iglesia y varias casas se dieron vuelta hasta los cimientos y si no hubo víctimas, lo debieron los habitantes al largo tiempo que tuvieron para salir afuera. Se ven todavía los rastros del terremoto. [...] Este lugarejo que se hallaba edificado sobre un terreno de rocas, fué del todo abatido, quedando sus restos como cortados á cincel (V.G.).

Chiu-Chiu.- - Sobre el terreno y cerca del volcán, según viajeros sorprendidos por el terremoto, se veían saltar las piedras del suelo con el temblor, haciendo sospechar que esa región se hallaba cerca del centro de conmoción (V.G.).

Si la extrema violencia del sismo destruyó el poblado de Chiu Chiu e hizo "saltar las piedras" del terreno en las proximidades del volcán (ise trata del volcán San Pedro?), es difícil que el conjunto arquitectónico de LR-ı haya salvado indemne. Por supuesto, hay muchas razones por las que un muro puede colapsar, incluyendo el paso del ganado, el debilitamiento de la argamasa por roces o lluvias, el desmantelamiento parcial de las estructuras para construir otras nuevas y, desde luego, terremotos ocurridos en otros períodos. Sin embargo, atendiendo a lo que muestra la estratigrafía, la etiqueta de la década de 1870 y el relato de Vidal Gormaz, sugerimos que fue el sismo de 1877 el que desempeñó el papel decisivo en la caída del mencionado muro oriental. Cálculos recientes indican que ese terremoto alcanzó una magnitud de $\mathrm{Mw}>8,5$ y que previo a él solo aquellos ocurridos en el norte de 


\section{LR-1, Estructura 7, Pozo 1 - PERFIL ESTE}

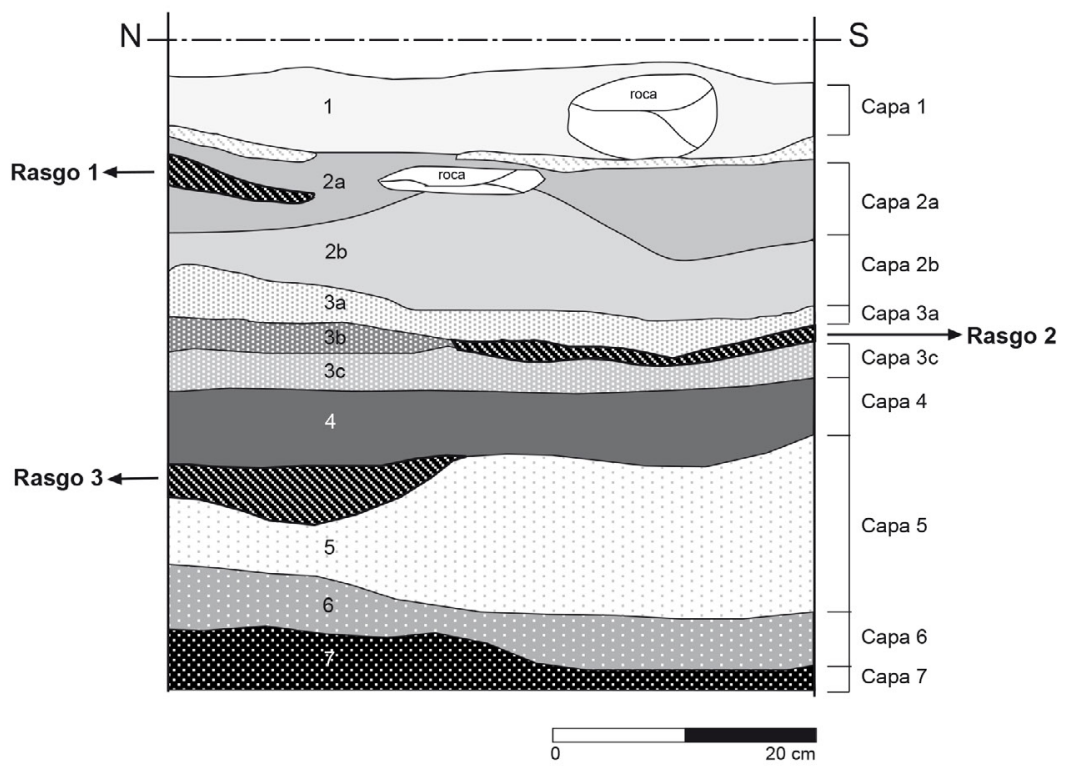

\section{LR-1, Estructura 7, Pozo 1 - PERFIL OESTE}

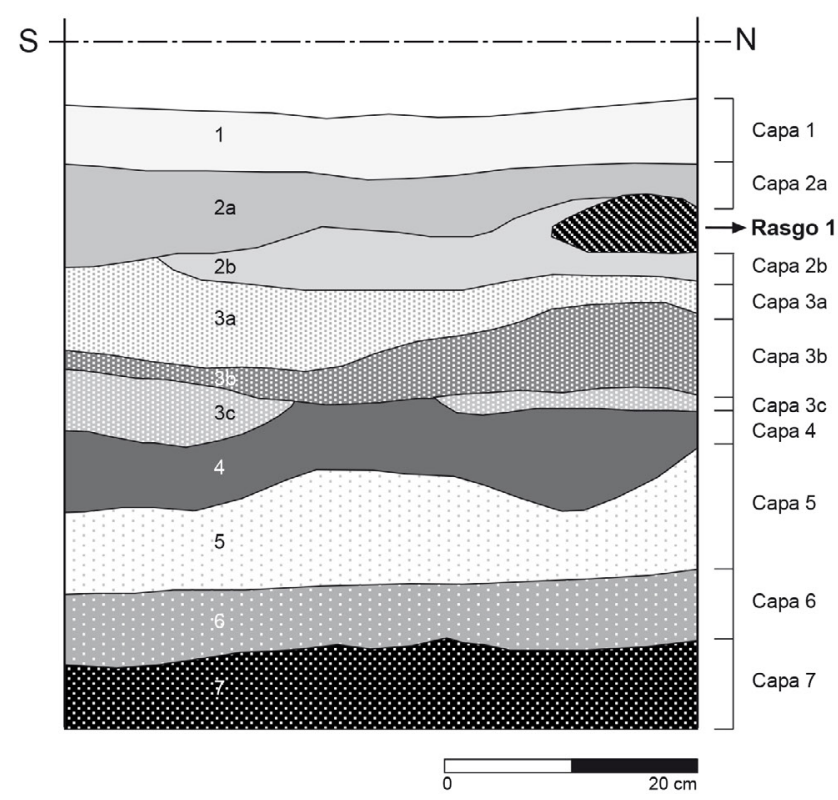

Dibujo, C. Sinclaire - 2016

Figura 14. Sitio LR-1: Corte estratigráfico en la Estructura 6/7. 


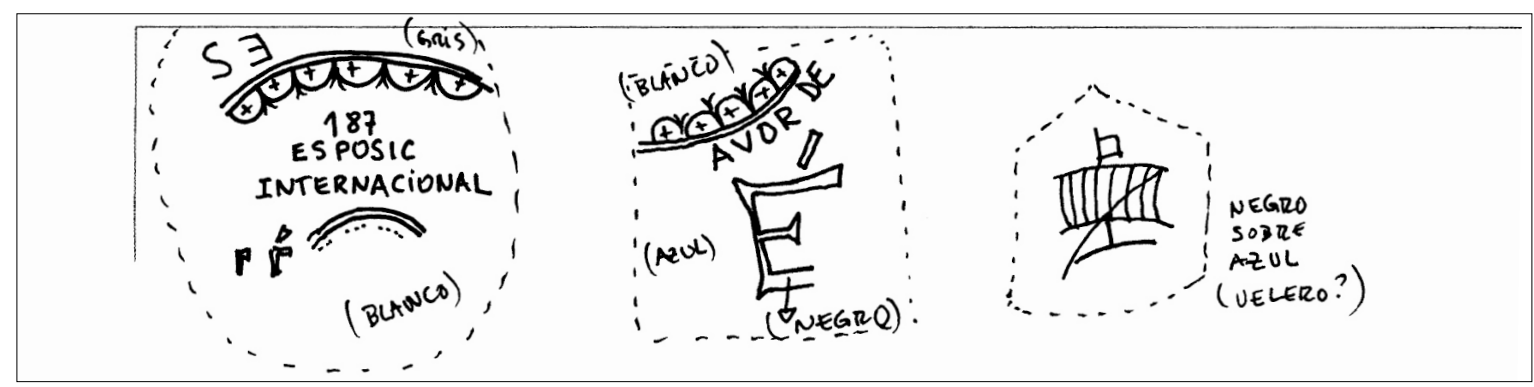

Figura 15. Croquis de la leyenda y las imágenes contenidas en diferentes trozos de una o más etiquetas registradas en la Estructura 5 de LR-1.

Chile en los años 1543, 1615 y 1768 podrían ser de magnitud mayor a Mw 7.0 (Ruiz et al. 2015: 2). Comte y Pardo (1991: 38) estiman que el epicentro del terremoto de 1877 se ubicó en $21,00^{\circ} \mathrm{S}, 70,25^{\circ} \mathrm{W}$ y que dados el daño reportado y el tsunami generado, es posible asumir una escasa profundidad. Estas coordenadas corresponden a un punto situado en el mar, frente a Río Seco, al sur de Pabellón de Pica, a solo unos $220 \mathrm{~km}$ al noroeste de Incaguasi. ${ }^{16}$

Algunos autores mencionan el terremoto de 1868 , pero si bien su magnitud fue similar, su epicentro habría estado localizado a $17,7^{\circ} \mathrm{S}, 71,6^{\circ} \mathrm{W}$ (Comte y Pardo 1991: 36), o sea, a más de $600 \mathrm{~km}$ al noroeste de Incaguasi. Demasiado lejos, quizás, como para causar daños importante en estas construcciones. Además, ocurrió antes de que la etiqueta supuestamente de la Exposición Internacional de Santiago, depositada en la Capa 1, se imprimiese, y, por lo tanto, antes que las piedras del muro cayeran sobre esta capa. Dado que tampoco ha habido un sismo de igual o mayor magnitud en la zona con posterioridad al mega terremoto de 1877 (de hecho se habla de una laguna sísmica de más de un siglo de duración en el Norte Grande [Nishenko 1985]), este último queda como el principal sospechoso del derrumbe del muro oriental de la Estructura $5 \mathrm{y}$, acaso, del derrumbe de varias de las principales estructuras del sitio LR-1.

En suma: en la Estructura 5 de este sitio tenemos depósitos atribuibles a un período anterior a 1841 (Capa 2b),

16 Es interesante notar que en el varias veces citado Mapa del teatro de la guerra (Raimondi 1878) Chiu Chiu aparece emplazado en el lado oeste del Loa, en circunstancias que después del terremoto de 1877 hubo que cambiarlo al lado este del río, lo que revela que, en el momento de su publicación, la información del mapa no había sido actualizada. otro acotado entre los años 1841 y 1877 (Capas 2a y 1) y un último posterior a 1877 (Capa Superficial y piedras del derrumbe). No es claro si la más profunda Capa 3 es atribuible a los siglos de la Colonia o al breve lapso en que las autoridades de Bolivia construyeron e intentaron mantener en funcionamiento un sistema de postas entre Cobija (Puerto Lamar) y Potosí (Cajías 1975). Para la primera posibilidad no hay muchas evidencias arqueológicas, salvo una cantidad notoriamente más baja de objetos de hierro y vidrio en relación a las capas superiores, y algunos fragmentos cerámicos clasificados como de la Colonia Temprana por presentar pastas con mica, un atributo considerado indicador de una época post contacto (Uribe y Cabello 2005). De tratarse, en cambio, de la segunda posibilidad, correspondería a un estrato formado durante los primeros 16 años de Bolivia como república independiente.

En todo caso, la importancia de la posta de Incaguasi en el sistema de postas de Cobija a Potosí no debiera exagerarse. Luego de mencionársele por primera vez en 1830 por el gobernador de la provincia, Gabino Ibáñez, de 10 itinerarios publicados hasta 1842 , ocho la omiten, incluyendo el algo más detallado Diario de Viaje de Atanasio Hernández; en cambio las vecinas postas de Cere, Santa Bárbara, Polapi (a veces mencionada en lugar de Pajonales) y Chiu Chiu prácticamente nunca faltan en esos itinerarios (Cajías 1975: 65-92, 384).

Extrañamente, Incaguasi presenta una cantidad de estructuras que excede en mucho "la habitación para pasajeros, el cuarto para el maestro de postas, el recinto para la cocina y el corral" que, a fines de 1830 , se decía debían tener las nueve postas recién construidas (Cajías 1975: 80), entre las cuales, dicho sea de paso, tampoco 
estaba la de Incaguasi. ¿A qué se deben este exceso y estas omisiones? Probablemente a que, en origen, el conjunto arquitectónico de LR-1 fue, como ya hemos visto, una instalación incaica y a que solo por encontrarse localizada en la ruta de Cobija a Potosí habría sido integrada al sistema de postas. Así, para quienes reportaban a las autoridades altiplánicas la construcción de las postas en 1830 tenía poco sentido mencionarla, ya que el edificio llevaba allí más de 300 años.

Es interesante destacar que, durante los 36 años que median entre el incendio de 1841 y el terremoto de 1877 , las estructuras arquitectónicas de LR-1 parecen haber estado casi siempre sin techo. Así lo sugieren lentes de arcilla y limo - descritos como "sellos de agua" en el momento de la excavación e interpretados como manchas de agua sedimentadas en gabinete- formados al parecer por lluvias excepcionales para un medio usualmente tan seco como el de Incaguasi. Al respecto, debe anotarse que la reconstrucción mediante anillos de árboles del registro de precipitaciones anuales en el siglo XIX muestra que este fue el más lluvioso de los últimos siete siglos y que de los cuatro eventos extremadamente húmedos ocurridos entre 1818 y 1887 , dos ocurren en el transcurso de esos 36 años: 1842-43 y 1876 (Morales et al. 2012: 659-66o, Fig. 4). Puede entenderse, entonces, la formación de ese tipo de sedimentos en los recintos durante aquel lapso.

La posible ausencia de techos implica que, como conjunto arquitectónico, la exposta habría permanecido muchas veces en desuso durante ese período, como lo indica, por lo demás, el Mapa del teatro de la guerra (Raimondi 1879), que incluye el topónimo "Ingahuasi" y debajo, la palabra "Abandonada" (véase Figura 3), ${ }^{17}$ así como su ausencia de varios otros registros documentales, tal como señalamos más arriba. Lo anterior no significa necesariamente que todas las estructuras hayan estado siempre abandonadas.

17 Según Bertrand (1885: 167-170), para hacer este mapa Raimondi se habría basado en el mapa escala 1:500.000 "El desierto de Atacama entre el grado 19 i el grado 24 de latitud sur", de Pedro Hoogsgaard [sic], cuyos datos de campo eran de 1873-1874 (de ahí su falta de actualización respecto de los estragos del terremoto de 1877 en Chiu Chiu). En realidad, el mapa de Raimondi dice que fue "formado sobre los trabajos de Smith y Bollaert, Philippi, Reck, Bresson y el plano inédito de Atacama de Hoecscaard". Agradecemos a Alonso Barros por habernos facilitado este importante mapa y autorizado a publicar un extracto de él. Una imagen completa se encuentra en Barros (2015: 489).
De hecho, Astaburuaga Cienfuegos (1899: 333) caracteriza al sitio como "caserío de pocos habitantes", aunque no sabemos de qué época data su información ni cuáles estructuras habrían estado "habitadas". Es posible que esa caracterización corresponda a una realidad de 1865 o anterior, dado que en el extracto citado por Bertrand (1885: 248-249) de la Guía Jeneral publicada en dicho año por Ernesto O. Rick, Incaguasi figura como "pueblo". Los superficiales muros pircados en el interior de las estructuras 5, 6/7 y 9, mencionados en nuestra descripción (ver supra), podrían corresponder a estos intermitentes y fugaces episodios de reocupación, para los que no se necesitaba acondicionar mayormente las ruinas del edificio. Puede postularse, entonces, que la Capa za de la Estructura 5, atribuible al lapso entre 1841 y 1877 , fue formada por múltiples usuarios esporádicos del sitio, probablemente arrieros, carreteros, comerciantes y contrabandistas que, en ocasiones, pasaban la noche en la estructura o simplemente la usaban para hacer una pausa a media jornada entre dos destinos. Lo que es más improbable es que el sitio haya seguido operando como posta propiamente tal, es decir, proveyendo atención y animales de refresco para los viajeros.

\section{* El período chileno}

Puesto que las piedras del derrumbe de 1877 cayeron sobre la Capa 1 del Sitio LR-1, donde apareció la etiqueta que hemos atribuido a 1875, la Capa Superficial que se formó alrededor y sobre esas piedras correspondería a los últimos años del Período Boliviano de Incaguasi y, a partir de 1904, al Período Chileno.

La parte inicial de este último período -incluso las décadas finales del Período Boliviano- parece estar todavía dentro del alcance de la tradición oral de los actuales habitantes del valle. En efecto, el recuerdo de muchos de ellos es que Incaguasi era un punto de descanso, un sitio para detenerse un rato, un corral para las mulas, una estancia de arrieros, un lugar donde pasaban la noche las carretas en tránsito hacia Bolivia.

Este es un lugar donde dormían las carretas cuando iban a Bolivia, ve que aquí está cerca del río, aquí estaba la cocina... Incaguasi nomás le llamaban, postas también, antes se veía desde acá, es que parece que se llevaron las piedras del muro, las cañerías botaron agua... es un corral muy regrande, o sea corral le llamamos nosotros, porque guardaban los animales... una estancia de los carreteros que iban a Bolivia, un día de viaje hasta Conchi, aquí 
descansaban los mulares, las carretas iban con pasto y se paraban aquí a descansar, después se acabaron las carretas y ahí se dejó de usar (I. P. en Gisoc 2009).

Es interesante, además, que muchos de estos testimonios descarten que el sitio haya sido un tambo incaico. Sostienen que es de una época de arrieros y carretas, y que fue usado por sus abuelos:

\section{[...] de hecho fue como Tambo pero no lo llamábamos así, era de arrieros, que llegaban y alojaban en esos corrales, ahí hay unas cuestas muy profundas porque el Loa es como muy hondo muy profundo, entonces hay unas cuestas más verticales por ahí por eso hay descanso [...] no... no es Tambo, es una estancia porque ahí encerraban los animales (L. H. en Gisoc 2009).}

Las referencias a "corrales" y a "encierro de animales" ofrecen vislumbres acerca de por qué el topónimo "Incaguasi" aparece asociado al topónimo "Establo" en la Carta "Conchi" del IGM (2003). Esta función se relacionaría con el arreo de animales desde 1880 en adelante con motivo del tráfico de ganado hacia la industria salitrera. En uno de sus últimos cambios funcionales, el lugar habría operado como "estancia", es decir, como aquellas casitas con uno o dos corrales que existen en el borde de las planicies del Alto Loa, junto a una cuesta y a un sendero tropero. Es posible que uno de los "corrales" nombrados no sea otro que la gran Estructura 3 de LR-1 (véase Figura 9). Después de todo, la pirca seca que corona varios de sus muros dobles originales, se halla tan bien conservada, que no puede sino ser posterior al violento terremoto de 1877; de otro modo estaría en el suelo como el resto de las estructuras del sitio LR-1 (véase p.e., Figura 10).

Otros entrevistados recuerdan haber pasado ellos mismos por Incaguasi, en viajes entre Chiu Chiu, Lasana y Santa Bárbara o Conchi Viejo. El viaje a este último pueblo lo hacían con motivo de procesiones y peregrinajes de la fiesta de la Virgen del Carmen.

[...] “tomábamos tecito ahí, y seguíamos, así lo conocí yo, entre todos llegaban ahí, igual la gente que llegaba a Conchi Viejo, a la fiesta, la gente venía de Lasana en animales, de ahí salía un ramal hacia Conchi Viejo, de la Estación de Conchi (A. G. en Gisoc 2009).

Niegan asimismo que el camino que pasa por este lugar fuese un camino inca.
[...] este es un camino tropero, con mulas, carretas que llevaban antes cuando estaba el tiempo de Bolivia... llevaban desde Mejillones ahí salían las carretas, desde Antofagasta [...] llevaban mercadería, ahí andaban cargadas más de 10 de un tiro... después de la guerra todavía se anduvo, pero ya no era tan transitada (I. P. en Gisoc 2009).

\section{$*$ Consideraciones finales}

Digamos al finalizar este artículo que el mapa de la internodalidad en el desierto de Atacama, lejos de ser uno de espacios vacíos, como quizás cabría esperar, es una red de recorridos de diferentes épocas que conectan vegas, áreas de recolección, cotos de caza, canteras, minas, talleres, aguadas, sitios rituales, refugios, caseríos, oasis, etc. (Berenguer 2010; Pimentel et al. 2011). Importantes en esta cartografía de la circulación son los llamados lugares de paso, concepto que aquí hemos hecho equivalentes con el de lugares de uso pasajero. Es cierto, como dice Ingold (2011), que en sentido estricto todos los lugares son de paso, ya que todos somos caminantes y vivimos nuestras vidas en líneas, sendas, huellas, senderos, calles, veredas, caminos, etc. Nadie vive inmóvil, recluido en un lugar toda su vida. Sin embargo, es evidente que hay lugares que son más pasajeros que otros. Dado que se sitúan en zonas de flujo, no son precisamente "lugares del estar", pero tampoco "lugares del andar" (sensu Careri 2009), sino asentamientos de permanente transitoriedad, destinados casi únicamente a la circulación y que son dejados atrás por sus intermitentes ocupantes tan rápidamente como es posible (cf. Bauman 2015a). Es tentador, pero erróneo asimilarlos a los "no lugares" (Augé 2001), esos espacios públicos y urbanos, de soledad y anonimato que caracterizan a la sobremodernidad, carentes de las manifestaciones simbólicas de la identidad, las relaciones y la historia, donde se acepta la inevitabilidad de una permanencia prolongada de extraños (Bauman 2015a: 110-111). La marca o sello identificador de los lugares pasajeros, en cambio, es que se localizan en zonas rurales, son usados de manera efímera por los viajeros, acogen ocasionales encuentros entre extraños y conocidos, son utilizados por múltiples usuarios diferentes, son objeto de insistencia ocupacional a lo largo de diferentes períodos y suelen experimentar sucesivas mutaciones funcionales.

Es interesante destacar esta dinámica procesual de los lugares de paso, porque este rasgo está en el centro de una noción materialista de lugar. Esta palabra, han dicho 
Lawson y Staeheli (1990: 17, citando a Pred 1986) es más útil entenderla como proceso que como objeto, ya que los lugares no son solamente puntos que se observan de manera fugaz en el paisaje, como una "localidad", ni siquiera simples "escenarios" para la actividad y la interacción social; son también lo que se desarrolla incesantemente, aquello que contribuye a la historia y la geografía en contextos específicos mediante la construcción social de un espacio físico. La trayectoria ocupacional de la pampa de Incaguasi, las actividades realizadas allí y los ciclos de vida de cada nueva "encarnación" funcional del lugar, tal como se desprende de nuestro estudio de la arquitectura y de los depósitos muestreados por nuestras excavaciones, evidencia este carácter procesual, esta contribución contextualmente específica a la geografía cultural e histórica del desierto como una construcción social diacrónica, en este caso a lo largo de alrededor de 800 años. Empero, evidencia también, quizás como un aspecto singular de esta pampa, que las diferentes "encarnaciones" de los sitios durante ese lapso no incluyeron la convergencia de otras funciones que derivaran en la generación de un lugar más complejo, algo así como un asentamiento de uso permanente, ya sea un caserío, una aldea o un pueblo.

En verdad, hay cientos y probablemente miles de lugares de paso en el desierto de Atacama, de modo que la ampliación de la casuística permitirá revisar en el futuro muchas de estas definiciones y generalizaciones tentativas. Por ahora, sin embargo, concentrémonos en sintetizar los resultados obtenidos en Incaguasi.

Desde mediados del Período Intermedio Tardío, y quizás de mucho antes, los viajeros que cubrían la ruta del Alto Loa pasaron por este paraje donde encontraban agua, forraje y abrigo. Con toda probabilidad, la gente circulaba por aquí desde el Período Arcaico, pero las excavaciones realizadas hasta ahora muestran actividad humana solo desde el siglo XIII en adelante, cuando individuos que circulaban por esta ruta funden en el sitio LR-2 mineral de cobre traído de Conchi Viejo o el Abra y tallan núcleos de calcedonia local para elaborar instrumentos líticos. En lo esencial, se trataría de pastores-caravaneros que dejan sus animales pastando a orillas del río y pasan la noche acampando en algunos de los precarios parapetos de piedra del lugar, ya sea a pampa abierta o en la abrigada quebradita donde, dos o tres siglos más tarde, los incas construirían su propio edificio. Durante esta épo- ca preincaica, todo es expeditivo en ese antiguo lugar de paskanas: la fundición de mineral de cobre, el tallado del material lítico y la sencilla arquitectura que cobijaba a los caravaneros. Todo, salvo las relaciones sociales. Es probable que, por lo general, el llamero y sus acompañantes pernoctasen solos en Incaguasi, pero que en ciertas ocasiones coincidieran con otras caravanas o transeúntes, en una "comunidad de semejantes" (sensu Bauman 2015b: 125) formada por ocupantes temporarios del lugar, comprometidos en relaciones momentáneas debido a la propia transitoriedad de la situación, pero seguramente con pasado y futuro por tratarse de conocidos, quizás colegas de oficio, vecinos, amigos, familiares o adversarios. Es difícil pronunciarse sobre la afiliación atacameña o foránea de estos caravaneros, dado el mencionado carácter "camaleónico" de estos, pero si el repertorio cerámico prevaleciente en el sitio es un buen indicador en este sentido, habría que concluir que provienen de la región.

A partir del siglo XV, los incas llegan al valle. Lo hacen principalmente para explotar las riquezas mineras de la Sierra del Medio, como efectivamente ocurre con las minas de Conchi Viejo y El Abra. Usan las viejas huellas troperas del valle como guía para trazar su propia vialidad, el Qhapaq Ñan del Alto Loa. Dado que la circulación estatal emplea también llameros y llamas cargueras, la localización y espaciamiento de las instalaciones incaicas en este camino sigue más o menos la misma lógica de las paskanas tradicionales, que, para adaptarse a la fisiología de los camélidos, obliga a segmentar las jornadas a distancias entre 15 y $25 \mathrm{~km}$ (Berenguer 2004a: 54). Durante el Período Inka, en la pampa de Incaguasi se mantiene en uso buena parte de las estructuras arquitectónicas del caravaneo de épocas anteriores. No obstante, en la somera quebradita de Incaguasi, que cobija al sitio LR-1, los incas desmantelan los campamentos caravaneros que hemos postulado había allí con anterioridad y edifican varios recintos alineados con la quebrada, entre ellos una kancha o RPC, en uno de cuyos cuartos habrían celebrado un rito de fundación del asentamiento. A diferencia de la época previa, en este nuevo período todo en LR-1 acusa planificación, un concepto más exigente respecto de lo que se considera habitable y una preocupación por la perdurabilidad del nuevo conjunto constructivo, como se infiere de la existencia de cimientos, de la buena calidad de los muros y de la creación de espacios techados. No se puede descartar que el tambillo haya sido 
gestionado por gente venida de afuera, pero, en concordancia con lo que se sabe sobre este tipo de sitios incaicos en otras partes (Hyslop 1984), está dentro de las probabilidades que haya sido gente de las vecindades (p.e., Lasana, Santa Bárbara, etc.) la que estuvo encargada por turnos de mantenerlo en funciones. Es decir, de traer agua del río, de asegurar un buen abastecimiento de víveres, de tener lista la leña y de atender a los pasajeros, incluyendo eventualmente a los correos o chaskis que operaban en este trayecto. Los llameros, en tanto, parecen haber sido autorizados por los agentes estatales para seguir usando tanto la ruta tropera paralela a la vía incaica como los campamentos caravaneros de antaño (LR-2), excepción hecha de los hipotéticos antiguos parapetos supuestamente desarmados por los incas al construir el tambillo. Se entrevé en esta coexistencia una relación de consentimiento mutuo, acaso colaborativa. Lo que ocurre es que Incaguasi era importante para los incas por tratarse del único lugar bien abastecido situado a una jornada de caravana de la siguiente parada. Además, viniendo de Chiu Chiu y Lasana, era el punto donde el camino se bifurcaba en una ruta que se dirigía a las minas de Conchi Viejo y El Abra, las que debían ser abastecidas por la economía política del Estado, y otra que lo hacía hacia Cerro Colorado, Miño y Collahuasi. En esta comunicación el tambillo de Incaguasi puede haber desempeñado la función de una estación intermedia, lo que explicaría su mayor tamaño en comparación con otros sitios de enlace que jalonan la ruta incaica del Alto Loa, como Bajada del Toro, Lequena, Desencuentro y Chela Inga (Berenguer et al. 2005).

Es muy poca la información sobre el Período Colonial brindada por las excavaciones; tan solo unos fragmentos de cerámica con mica, presumiblemente de fecha post contacto. Proponemos como hipótesis de trabajo que, después del colapso del Tawantinsuyu a manos de los españoles, se produjo en la zona un rápido abandono de los sitios estatales (al respecto, véase Lynch 1993: 129), incluyendo el abandono de tambillos como el de Incaguasi, circunstancia esta última aprovechada por los caravaneros locales para reinstalar sus paskanas en la quebradita somera, tal vez cerca o en las propias ruinas del edificio incaico. En otras palabras: mientras el ciclo de vida de Incaguasi como tambillo es corto y concluye abruptamente con el arribo de los conquistadores, el ciclo de vida de Incaguasi como paskana continúa después del contacto europeo. Aunque no por mucho tiempo: muy pronto ese caravaneo tradicional empieza a coexistir con otro crecientemente mercantil, mezclado con flujos de comerciantes, correos, mineros y agentes coloniales, que probablemente contribuyen a disociar o diluir la "comunidad de semejantes" que prevalecía en la época preincaica, incluso durante la presencia inca. Con el reemplazo en el siglo XVII de la llama por la mula, un animal con una autonomía de marcha tres veces superior a la primera, Incaguasi habría pasado a ser una simple parada a media jornada de camino, concluyendo así el ciclo de vida del lugar como zona de paskanas del caravaneo tradicional.

Nuestro estudio del Período Boliviano en la pampa de Incaguasi, en tanto, sugirió respuestas para dos importantes interrogantes sobre LR-1: ¿por qué en el sistema de postas entre Cobija y Potosí, implementado por el gobierno de Bolivia a partir de 1830, Incaguasi es mencionado en los documentos en forma tan escasa e irregular y a qué se debe que la cantidad de recintos de LR-1 sobrepase en mucho la cantidad de cuartos que se supone debían tener las postas de ese sistema? Respecto a la primera de estas interrogantes, sostenemos que la irregularidad obedece a que Incaguasi nunca integró la lista titular de postas del sistema, manteniéndose solo como una alternativa para ciertas ocasiones o circunstancias. En cuanto a la segunda interrogante, creemos que se explica, precisamente, porque el edificio fue diseñado originalmente como una instalación incaica, no como una posta. Otro aporte interesante son las evidencias que proporcionaron las excavaciones en LR-1 sobre el incendio del edificio en 1841 , las precipitaciones inusuales en un siglo inusualmente lluvioso y el mega terremoto de 1877, eventos que permitieron acotar cronológicamente un muy bien definido episodio de 36 años dentro del más amplio Período Boliviano (1825-1904). Si bien el carácter de posta putativa de Incaguasi cesó con el siniestro de 1841, el lugar continuó ejerciendo la función de sitio de travesía de manera informal, aunque a partir de entonces su equipamiento parece haber dejado mucho que desear, toda vez que hay evidencia sedimentaria de que el interior de los cuartos estuvo muchas veces expuesto a la lluvia por falta de techumbre. Más allá de uno que otro dato que sugiere esporádicos episodios de reocupación del sitio (Bertrand 1885; Astaburuaga Cienfuegos 1899), el edificio parece haber permanecido abandonado durante décadas (Raimondi 1878), operando el lugar, no obstante, como un informal punto de detención (y 
eventualmente de pernocte) para una gran variedad de viajeros, pero, sobre todo, para el tráfico de carretas y el arreo de ganado. Cabe notar que la ocupación chilena con motivo de la Guerra del Pacífico, el movimiento de soldados y el tránsito de funcionarios del Estado de Chile, que deben haber pasado por Incaguasi a partir de 1879, no fueron evidentes en las unidades excavadas.

En cuanto al Período Chileno (1904-presente), es interesante que terminada la primera década del siglo XXI todavía haya habitantes del Loa que cuenten que las carretas hacían noche en Incaguasi. Podría pensarse que es el poder de la tradición oral, de las conversaciones de generación en generación. Sin embargo, no estamos seguros de si estas menciones se refieren al tráfico decimonónico o a uno más reciente, quizás acaecido durante la primera mitad del siglo XX, como podría ser el traslado de llareta y bórax. Pero también están los testimonios más actuales de quienes, cuando niños, viajaban a pie, solos o con burros, a Lasana o Chiu Chiu y paraban a descansar en los "corrales" del lugar. En fin, la trayectoria ocupacional de Incaguasi es una historia de continuidades y discontinuidades, en la que a lo largo de ocho siglos el lugar no ha dejado de mutar: de paskana a tambillo, de tambillo a paskana de nuevo, de paskana a posta, de posta a parada de carretas y de esta última a corral y lugar de descanso a media jornada. La próxima mutación vendrá seguramente cuando se inaugure (si tal cosa ocurre) el circuito turístico del camino inca en la región de Antofagasta, ya que el sitio integra la nominación del Qhapaq Ñan en la Lista de Patrimonio Mundial de la Unesco y, como parte de su puesta en valor, el programa contempla el emplazamiento de carteles con textos interpretativos. Buen desafío el de esa futura encarnación patrimonializada de Incaguasi, toda vez que, por un lado, se tendrá el conocimiento científico-académico sobre el lugar, y por otro, el relato étnico-comunitario, los que no siempre coinciden (Darvill 2007; Berenguer et al. 2012). Para los científicos, el primero representará siempre solo el mejor conocimiento posible acerca del lugar hasta que surjan nuevos datos; para la memoria local, en cambio, seguirá siendo por mucho tiempo "el lugar donde dormían las carretas".

Agradecimientos A FONDECYT y El Abra por la financiación de nuestros respectivos proyectos. A nuestros coinvestigadores, tesistas, personal técnico de apoyo en terreno y profesionales de distintas especialidades cuyo aporte ha sido reconocido en las notas a pie de página, en los pies de ilustraciones $y / o$ en las referencias bibliográficas. Quisiéramos destacar también el aporte de Carole Sinclaire en el dibujo de los cortes estratigráficos. Un reconocimiento especial a los colegas Roberto Bárcena y Mercedes Podestá por sus valiosas colaboraciones. Finalmente, un agradecimiento a los evaluadores anónimos del manuscrito.

\section{$\bullet$ Referencias citadas}

ADÁN, L. 1999. Aquellos antiguos edificios. Acercamiento arqueológico. Estudios Atacameños 18: 13-33.

ALDUNATE, C. 2001a. El Inka en Tarapacá y Atacama. En Tras la huella del Inka en Chile, C. Aldunate y L. Cornejo (Eds.), pp. 18-33. Museo Chileno de Arte Precolombino / Banco Santiago, Santiago de Chile.

ALDUNATE, C. 20olb. El dominio del Tawantinsuyu sobre Turi. En Tras la huella del Inka en Chile, C. Aldunate y L. Cornejo (Eds.), pp. 38-43. Museo Chileno de Arte Precolombino / Banco Santiago, Santiago de Chile.

ALDUNATE, C., J. BERENGUER y V. CASTRO. 1983. Estilos de arte rupestre en el Alto Loa. Creces 4 (3): 21-28.
ANGIORAMA, C. 2006. ¿Mineros quebradeños o altiplánicos? La circulación de metales y minerales en el extremo noroccidental de Argentina (1280-1535 AD). Intersecciones en Antropología 7: 147-161.

ARCE, R. 2004 [1930]. Narraciones históricas de Antofagasta. Tercera edición. Ediciones PROA, Antofagasta.

ASTABURUAGA CIENFUEGOS, F. S. 1899. Diccionario Geográfico de la República de Chile. Segunda edición, corregida y aumentada, Santiago de Chile.

AUGÉ, M. 2001. Los no lugares. Espacio del anonimato. Una antropología de la sobremodernidad. Gedisa, Barcelona.

BARKER, P. 1977. The techniques of archaeological excavation. B.T. Batsford Ltd., London. 
BARNARD, H. y W. WENDRICH. 2008. The archaeology of mobility: definitions and research approaches. En The archaeology of mobility. Old World and New World nomadism, H. Barnard y W. Wendrich (Eds.), pp. 1-21. The Cotsen Institute of Archaeology at UCLA, Los Angeles.

BARROS, A. 2008. Identidades y propiedades: transiciones territoriales en el siglo XIX atacameño. Estudios Atacameños. Arqueología y Antropología Surandinas 35: 119-139.

BARROS, A. 2010. Tsunami en Bolivia y Perú: El terremoto y salida de mar del 9 de mayo de 1877 (Norte Grande, Chile). Revista Ciencias Sociales 24: 73-93.

BARROS, A. 2015. Revolución chilena, litoral boliviano: La Patria, la Compañía de Salitres y los prolegómenos de la Guerra del Pacífico en el desierto de Atacama (1870-1879). Revista de Antropología Experimental 15, Texto 27:483-520, http://revistaselectronicas.ujaen.es/index.php/rae

BAUMAN, Z. 2015a. Modernidad líquida. FCE, México, D.F.

BAUMAN, Z. 2015b. Tiempos líquidos. Vivir en una época de incertidumbre. Tercera reimpresión argentina. Tusquets Editores, Buenos Aires.

BERENGUER, J. 1994a. Asentamientos, caravaneros y tráfico de larga distancia en el norte de Chile: el caso de Santa Bárbara. En De costa a selva: intercambio y producción en los Andes CentroSur, M. E. Albeck (Ed.), pp. 17-50. Instituto Interdisciplinario Tilcara, Jujuy.

BERENGUER, J. 1994b. Recientes hallazgos de evidencias inkaicas en el Sector Santa Bárbara, Alto Loa. Boletín de la Sociedad Chilena de Arqueología 18: 10-16.

Berenguer, J. 1995. Impacto del caravaneo prehispánico tardío en Santa Bárbara, Alto Loa. En Actas del XIII Congreso Nacional de Arqueología Chilena, Tomo I: 185-202, Antofagasta, Hombre y Desierto 9.

Berenguer, J. 1999. El evanescente lenguaje del arte rupestre en los Andes atacameños. En Arte rupestre en los Andes de Capricornio. J. Berenguer y F. Gallardo (Eds.), pp. 9-56. Museo Chileno de Arte Precolombino / Banco Santiago, Santiago de Chile.

BERENGUER, J. 2004a. Caravanas, interacción y cambio en el desierto de Atacama. Sirawi Ediciones, Santiago de Chile.

BERENGUER, J. 2004b. Cinco milenios de arte rupestre en los Andes atacameños: imágenes para lo humano, imágenes para lo divino. Boletín del Museo Chileno de Arte Precolombino 9: 75-108.
BERENGUER, J. 2007. El camino inka del Alto Loa y la creación del espacio provincial en Atacama. En Producción y circulación prehispánicas de bienes en el sur andino, A. Nielsen et al. (Comps.), pp. 413-443. Editorial Brujas, Córdoba.

BERENGUER, J. 2010. Estrategias ocupacionales incaicas en dos espacios internodales del norte de Chile. En Actas del XVII Congreso Nacional de Arqueología Chilena, Valdivia, 2006, "Simposio Arqueología de los 'espacios vacíos': una aproximación internodal a las relaciones intersocietales", J. Berenguer y G. Pimentel (Coords.), pp. 1389-1401. Sociedad Chilena de Arqueología / Universidad Austral de Chile, Valdivia.

BERENGUER, J. e I. CÁCERES 2008a. El Qhapaq Ñan en Chile. Tramo 2: Miño - Lasana, Región de Antofagasta. Informe técnico presentado al programa Qhapaq Ñan-Chile, Consejo de Monumentos Nacionales, Santiago de Chile.

BERENGUER, J. e I. CÁCERES. 2008b. Los inkas en el altiplano sur de Tarapacá: el Tojo revisitado. Chungara. Revista de Antropología Chilena 40 (2): 121-143.

BERENGUER, J., I. CÁCERES, C. SANHUEZA y P. HERNÁNDEZ. 2005. El Qhapaqñan en el Alto Loa, norte de Chile: un estudio micro y macromorfológico. Estudios Atacameños 29: 7-39.

BERENGUER, J. y G. PIMENTEL. 2010. Presentación. Simposio Arqueología de los 'espacios vacíos': una aproximación internodal a las relaciones intersocietales. En Actas del XVII Congreso Nacional de Arqueología Chilena, Valdivia, 2006, pp. 1305-1308. Sociedad Chilena de Arqueología / Universidad Austral de Chile, Valdivia.

BERENGUER, J. y D. SALAZAR. 2017. Territorialización del modelo minero inkaico en el río Salado: una aglomeración productiva entre Lípez y San Pedro de Atacama. Boletín del Museo Chileno de Arte Precolombino 21 (1): 51-69.

BERENGUER, J., C. SANHUEZA e I. CÁCERES. 2011. Diagonales incaicas, interacción interregional y dominación en el altiplano de Tarapacá, norte de Chile. En En ruta: arqueología, historia y etnografía del tráfico sur andino, L. Núñez y A. Nielsen (Eds.), pp. 247-283. Encuentro Grupo Editor, Córdoba.

BERENGUER, J., C. SANHUEZA, C. VITRY, P. OLAVARRÍA y A. TORRES. 2012. Qhapaq Nan. Las rutas del Inca en el norte de Chile. Segunda edición. Consejo de Monumentos Nacionales / Qhapaq Ñan Chile, Santiago de Chile.

BERTRAND, A. 1885. Memoria sobre las cordilleras del desierto de Atacama y regiones limitrofes. Imprenta Nacional, Santiago de Chile. 
BOLETÍN DE LA GUERRA DEL PACÍFICO. 1979. Boletín de la Guerra del Pacífico 1879-1881. Editorial Andrés Bello, Santiago de Chile.

CAJÍAS, F. 1975. La Provincia de Atacama (1825-1842). Instituto Boliviano de Cultura, La Paz.

CARERI, F. 2009. Walkscapes. El andar como práctica estética. Land \& Scape Series, Editorial Gustavo Gili, SL, Barcelona.

COMTE, D. y M. PARDO 1991. Reappraisal of great historical earthquakes in the Northern Chile and Southern Peru seismic gaps. Natural Hazards 4: 23-44.

CORNEJO, L. 1995. El Inka en la Región del río Loa: lo local y lo foráneo. En Actas del XIII Congreso Nacional de Arqueología Chilena, pp. 203-212. Sociedad Chilena, Antofagasta.

CORRALES, P. 2017. Complejo minero San José del Abra. Vialidad, producción y administración Incaica en el Alto Loa. Memoria para optar al título de Arqueóloga, Departamento de Antropología, Universidad de Chile, Santiago.

DALENCE, J. M. 1851. Bosquejo estadístico de Bolivia. Imprenta de Sucre, Chuquisaca.

DARVILL, T. 2007. Research frameworks for World Heritage Sites and the conceptualization of archaeological knowledge. World Archaeology 39 (3): 436-457.

DEL PINO MANRÍQUEZ, J. 1787 [1885]. Descripción de la Villa de Potosí y los partidos sujetos a su intendencia. En Memoria sobre las cordilleras del desierto de Atacama y sus regiones limitrofes, A. Bertrand. Imprenta Nacional, Santiago de Chile.

DE SOUZA, P. 2004. Cazadores recolectores del Arcaico Temprano y Medio de la cuenca superior del río Loa: sitios, conjuntos líticos y sistemas de asentamientos. Estudios Atacameños 27: 7-43.

GARCILASO DE LA VEGA, I. 1943 [1604]. Comentarios reales de los incas, Tomo II. Emecé Editores S.A., Buenos Aires.

GISOC. 2009. Diagnóstico de situación del Qhapaq Ñan en Chile: componente etnográfico. Segundo informe presentado a la Subsecretaría de Desarrollo Regional y Administrativo / Consejo de Monumentos Nacionales. Gisoc Consultoría Ltda., Santiago de Chile.

GONZÁLEZ, C. 2004. Ms. Asentamientos de enlace y su relación con el camino del Inka del Alto Loa: un enfoque arqueoarquitectónico. Borrador de Memoria para optar al título profesional de Arqueólogo.
GONZÁLEZ PIZARRO. 2006. Vialidad moderna. En Las rutas del Capricornio andino, A. Cabezas, M. I. Hernández, L. Núñez y Mario Vásquez (Eds.), pp. 153-162. Consejo de Monumentos Nacionales, Santiago de Chile.

HYSLOP, J. 1984. The Inka road system. Academic Press, Orlando.

IGM 2003. Carta Regular de Chile "Conchi", Escala 1:50.000. Segunda edición. Instituto Geográfico Militar, Santiago de Chile.

IGM 2003. Carta Regular "Estación San Pedro". Escala 1:50.000. Segunda edición. Instituto Geográfico Militar, Santiago de Chile.

INGOLD, T. 2011. Against space: place, movement, knowledge. En Boundless worlds: an anthropological approach to movement, P. W. Kirby (Ed.), pp. 30-43, 1st Paperback Edition. Berghahn Books, Oxford.

LAWSON, V. A. y L. A. STAEHELI. 1990. Realism and the practice of geography. Professional Geographer 42 (1): 13-20.

LINDBERG, I. 1969. Conchi Viejo: una capilla y ocho casas. En Actas del V Congreso Nacional de Arqueología, pp. 59-73. Museo Arqueológico de La Serena, La Serena.

LOZANO MACHUCA, J. 1581 [1885]. Carta del factor de Potosí Juan Lozano Machuca al virrey del Perú, en donde se describe la provincia de los Lipes. En Relaciones Geográficas de Indias, Perú, Tomo II, Apéndice III, pp. xxi-xxviii, Madrid.

LYNCH, R. F. 1993. The identification of inca posts and roads from Catarpe to Río Frío, Chile. En Provincial inca. Archaeological and ethnohistorical assessment of the impact of the Inca State, M. A. Malpass (Ed.), pp. 117-142, University of Iowa Press, Iowa City.

MELERO, D. y D. SALAZAR. 2003. Historia colonial de Conchi Viejo y San José del Abra, y su relación con la minería en Atacama. Revista Chilena de Historia Indígena 7: 55-86.

MARINOVIC, N. y A. LAHSEN. 1984. Hoja Calama, Región de Antofagasta. En Carta Geológica de Chile, Escala 1:250.000, núm. 58. Servicio Nacional de Geología y Minería, Santiago de Chile.

MÉNDEZ, C. 2007. Tecnología lítica en el camino Inca del Alto Loa, norte de Chile. Estudios Atacameños. Arqueología y Antropología Surandinas 33:39-57.

MONTESSUS DE BALLORE F., 1912. Historia sísmica de los Andes meridionales. Segunda Parte, Imprenta Cervantes, Santiago de Chile. 
MORALES, M., D. A. CHRISTIE, R. VILLALBA, J. ARGOLLO, J. PACAJES, J. S. SILVA, C. A. ÁlVAREZ, J. C. LlANCABURE y C. C. SOLIZ GAMBOA. 2012. Precipitation changes in the South American altiplano since $1300 \mathrm{AD}$ reconstructed by treerings. Climate of the Past 8: 653-666.

NIELSEN, A. 1997. El tráfico caravanero visto desde La Jara. Estudios Atacameños 14: 339-371.

NIELSEN, A. 2006. Estudios internodales e interacción interregional en los Andes circumpuneños: teoría, métodos y ejemplos de aplicación. En Esferas de interacción prehistóricas y fronteras nacionales modernas en los Andes sur centrales, H. Lechtman (Ed.), pp. 2962. Instituto de Estudios Peruanos, Lima.

NIELSEN, A. 2013. Circulating objects and the constitution of south Andean society (500 BC-AD 1550). En Merchants, markets, and exchange in the pre-Columbian world, K. Hirth and J. Pillsbury, pp. 389-418. Dumbarton Oaks Research Library and Collection, Washington D.C.

NISHENKO, S. P. 1985. Seismic potential for large and great interplate earthquakes along the Chilean and Southern Peruvian margins of South America: a quantitative reappraisal. Journal of Geophysical Research 90: 3589-3615.

PIMENTEL, G. 2009. Las huacas del tráfico. Arquitectura ceremonial en rutas prehispánicas del desierto de Atacama. Boletín del Museo Chileno de Arte Precolombino 14 (2): 9-38.

PIMENTEL G., C. REES, P. DE SOUZA y L. ARANCIBIA. 2011. Viajeros costeros y caravaneros. Dos estrategias de movilidad en el Período Formativo del desierto de Atacama, Chile. En En ruta: arqueología, historia y etnografía del tráfico sur andino, L. Núñez y A. Nielsen (Eds.), pp. 43-81. Encuentro Grupo Editor, Córdoba.

PODESTÁ, M. M., D. S. ROLANDI, A. RE, M. P. FALCI y O. DAMIANI. 2006. Arrieros y marcas de ganado. Expresiones de arte rupestre de momentos históricos en el desierto de Ischigualasto. En Tramas en la piedra. Producción y usos del arte rupestre, D. Fiore y M. M. Podestá (Eds.), pp. 169-190. Sociedad Argentina de Antropología, Asociación Amigos del INA y World Archaeological Congress, Buenos Aires.

RAIMONDI, A. 1879. Mapa del teatro de la guerra de las repúblicas aliadas Perú y Bolivia con Chile, formado sobre los trabajos de Smith y Bollaert, Philippi, Reck, Bresson y el plano inédito sobre el desierto de Atacama de P. Hoogsgaard.

RISOPATRÓN, L. 1924. Diccionario Jeográfico de Chile. Imprenta Universitaria, Santiago de Chile.
RUIZ, S., M. METOIS, R. GRANDIN, E. RIVERA, S. LEÓN, S. CARARO, A. FUENZALIDA, M. VALLEE, F. LEYTON, J. RUIZ, C. VIGNY, R. MADARIAGA y J. CAMPOS 2015. Los terremotos de Iquique 2014. En XI Congreso Chileno de Sismología e Ingeniería Sísmica ACHISINA, pp. 1-12, Santiago de Chile.

SALAZAR, D. 2006. Arqueología colonial en Atacama. Rescate de los sitios AB-11, ABı1b y AB-114. Ms. en posesión de los autores.

SALAZAR, D. 2008. La producción minera en San José del Abra durante el Período Tardío atacameño. Estudios Atacameños. Arqueología y Antropología Surandinas 36: 43-72.

SALAZAR, D.; J. BERENGUER y G. VEGA. 2013. Paisajes minerometalúrgicos incaicos en Atacama y el altiplano sur de Tarapacá (norte de Chile). Chungara. Revista de Antropología Chilena 45 (1): 83-103.

SALAZAR, D. y C. BORIE. 2013. Profundización del conocimiento sobre el complejo minero San José del Abra. Informe final de proyecto, 2 vols. Ms. en posesión de los autores.

SANHUEZA, M. C. 1991. Origen y desarrollo de la arriería indígena colonial en Atacama, siglos XVI-XVIII. Tesis para optar al grado de Licenciada en Historia, Pontificia Universidad Católica de Chile, Santiago de Chile.

SANHUEZA, M. C. 2005. Espacio y tiempo en los límites del mundo. Los incas en el despoblado de Atacama. Boletín del Museo Chileno de Arte Precolombino 10 (2): 51-77.

SANHUEZA, C. 2012. Las 'sayhuas' del Inca. Territorio, frontera, geografía sagrada y 'cartografía' oral en el desierto de Atacama. Tesis para optar el grado de Doctora en Historia con Mención en Estudios Andinos, Pontificia Universidad Católica de Chile, Santiago.

SANHUEZA, C. y H. GUNDERMANN. 2007. Estado, expansión capitalista y sujetos sociales en Atacama (1879-1928). Estudios Atacameños. Arqueología y Antropología Surandinas 34: 113-136.

SANHUEZA, C. y H. GUNDERMANN. 2009. Capitales, estado rentista y cambio social atacameño en las regiones interiores de Antofagasta (1879-1928). Universum 24 (1): 218-246.

SMITH, A. B. 2008. Is absence of evidence, evidence of absence? Problems in the archaeology of early herding societies of Southern Africa. En The archaeology of mobility. Old World and New World nomadism, H. Barnard y W. Wendrich (Eds.), pp. 264-279. The Cotsen Institute of Archaeology at UCLA, Los Angeles. 
SNEAD, J. E.; C. L. ERICKSON y J. ANDREW DARLING. 2009. Making human space: the archaeology of trails, paths, and roads. En Landscapes of movement. Trails, paths, and roads in anthropological perspective, J. E. Snead, C. L. Erickson y J. Andrew Darling (Eds.), pp. 1-19. University of Pennsylvania Museum of Archaeology and Anthropology, Philadelphia.

STEHBERG, R. 2001. Los caminos inka en Chile. En Tras la huella del Inka en Chile, C. Aldunate y L. Cornejo (Eds.), pp. 92-103. Museo Chileno de Arte Precolombino / Banco Santiago, Santiago de Chile.

THOMSON, I. 2006. Los ferrocarriles del Capricornio andino. En Las rutas del Capricornio andino, A. Cabezas, M. I. Hernández, 1. Núñez y Mario Vásquez (Eds.), pp. 139-149. Consejo de Monumentos Nacionales, Santiago de Chile.
URIBE, M. y G. CABELLO. 2005. Cerámica en el camino: los materiales del río Loa (Norte Grande de Chile) y sus implicancias tipológicas y conductuales para la comprensión de la vialidad y la expansión del Tawantinsuyo. Revista Española de Antropología Americana 35: 75-98.

VARELA V., M. URIBE y L. ADÁN. 1993. La cerámica arqueológica del sitio "pukara" de Turi, O2-Tu-002. En Actas del XII Congreso de Arqueología Chilena, Tomo 2, pp. 107-122. Boletín del Museo Regional de la Araucanía 4, Temuco.

VILLASECA. M. DE LOS A. 1998. Entre luces y sombras: etnoarqueología de pastores del Alto Loa. Memoria para optar al título profesional de Arqueólogo, Departamento de Antropología de la Universidad de Chile, Santiago de Chile. 